Article

\title{
Experimental and CFD Simulations of the Aerosol Flow in the Air Ventilating the Underground Excavation in Terms of SARS-CoV-2 Transmission
}

\author{
Tomasz Janoszek $^{1, * \mathbb{D}}$, Zbigniew Lubosik ${ }^{2} \mathbb{D}$, Lucjan Świerczek ${ }^{3}$, Andrzej Walentek ${ }^{1}$ and Jerzy Jaroszewicz $^{4}$ \\ 1 Department of Extraction Technologies, Rockburst and Mining Support, Central Mining Institute, \\ Plac Gwarków 1, 40-166 Katowice, Poland; awalentek@gig.eu \\ 2 Geoengineering and Industrial Safety, Central Mining Institute, Plac Gwarków 1, 40-166 Katowice, Poland; \\ zlubosik@gig.eu \\ 3 Department of Mining Aerology, Central Mining Institute, Plac Gwarków 1, 40-166 Katowice, Poland; \\ 1swierczek@gig.eu \\ 4 Department of Infectious Diseases and Hepatology, Medical University of Silesia, Aleja Legionów 49, \\ 41-902 Bytom, Poland; jjaroszewicz@sum.edu.pl \\ * Correspondence: tjanoszek@gig.eu; Tel.: +48-32-259-2307
}

Citation: Janoszek, T.; Lubosik, Z; Świerczek, L.; Walentek, A.;

Jaroszewicz, J. Experimental and CFD Simulations of the Aerosol Flow in the Air Ventilating the Underground Excavation in Terms of SARS-CoV-2 Transmission. Energies 2021, 14, 4743. https://doi.org/10.3390/en14164743

Academic Editor: Behnam Zakeri

Received: 26 May 2021

Accepted: 17 July 2021

Published: 4 August 2021

Publisher's Note: MDPI stays neutral with regard to jurisdictional claims in published maps and institutional affiliations.

Copyright: (C) 2021 by the authors. Licensee MDPI, Basel, Switzerland. This article is an open access article distributed under the terms and conditions of the Creative Commons Attribution (CC BY) license (https:/ / creativecommons.org/licenses/by/ $4.0 /)$.

\begin{abstract}
The paper presents the results of experimental and model tests of transport of dispersed fluid droplets forming a cloud of aerosol in a stream of air ventilating a selected section of the underground excavation. The excavation selected for testing is part of the ventilation network of the Experimental Mine Barbara of the Central Mining Institute. For given environmental conditions, such as temperature, pressure, relative humidity, and velocity of air, the distribution of aerosol droplet changes in the mixture of air and water vapor along the excavation at a distance was measured at $10 \mathrm{~m}, 25 \mathrm{~m}$, and $50 \mathrm{~m}$ from the source of its emission. The source of aerosol emission in the excavation space was a water nozzle that was located $25 \mathrm{~m}$ from the inlet (inlet) of the excavation. The obtained results of in situ tests were related to the results of numerical calculations using computational fluid dynamics (CFD). Numerical calculations were performed using Ansys-Fluent and Ansys-CFX software. The dimensions and geometry of the excavation under investigation are presented. The authors describe the adopted assumptions and conditions for the numerical model and discuss the results of the numerical solution.
\end{abstract}

Keywords: aerosol; underground mine; modelling; CFD

\section{Introduction}

The COVID-19 pandemic has resulted in the long-term lockdown of people all over the world. In addition to restrictions on the movement of people, the World Health Organization (WHO), including governments, have ordered people to keep a so-called social distance of approximately $2 \mathrm{~m}$ from each other in order to minimize the risk of infection with SARS-CoV-2, which is mainly spread through nose and mouth droplets. However, this assumption is based on the fact that there is no air circulation around people. There are justified concerns about the possibility of SARS-CoV-2 airborne transmission due to the fact of its persistence in aerosol droplets in a viable and infectious form. Based on the available literature and observations, it is likely that small particles containing the virus can be transported in the external environment at a considerable distance from the sources of emission, which is a type of aerosol transfer [1-4].

It is not well researched whether the movements of air masses, humidity, and temperature will cause the droplets of the fluid to be transported further with the air over long distances and cause the social distancing policy to be insufficient. This problem largely affects the mining sector, where a complex network of underground excavations creates complex airflow paths. 
By aerosols, it is meant an irregular diffuse phase of fluid in the form of a droplet that, depending on the particle size, either floats in the air stream over long distances or falls rapidly [5]. After the release of aerosol droplets, the main factors determining movement are the size of the droplet and the velocity of the airflow. The size of the drops varies with time, depending on the ambient conditions. Humidity in the air changes the rate of evaporation of the droplets and, thus, its size. Droplets in dry air evaporate quickly, decrease and fall to the ground more slowly. Changing droplet size affects how it reacts to the flow of air masses and how quickly it stabilizes [6,7]. The respiratory droplets formed during sneezing or coughing are generated both from saliva (the so-called "coarse" droplets) and from the mucous membrane of the lungs and vocal cords (the so-called "fine" and "ultra-fine" droplets with a smaller diameter). Smaller droplets are often invisible to the naked eye. Studies carried out by [8] have shown that most of the respiratory droplets do not move independently along their trajectories and that saliva droplets in the size range are "captured" and carried as an aerosol [8]. Regarding voice modulation, in [9], the authors showed that while voice elevation increases the number of respiratory droplets emitted with an exhalation, the size range remains unchanged.

According to WHO data, the main route of SARS-CoV-2 infection is an airborne pathway [1,4]. However, the scientific community is currently debating whether SARSCoV-2 can also spread in aerosols. The press is increasingly raising hypotheses about possible mechanisms of SARS-CoV-2 transfer through aerosols [10]. The fact that the respiratory drops are carriers of the virus is undeniable [11]. However, the question of aerosol transmission routes in the surrounding environment and the concentration of viruses capable of causing infection present in the environment in which the aerosol was sprayed remains under discussion.

The size of the drops varies with time, depending on the ambient conditions. Humidity in the air affects the rate of evaporation of the droplets and, thus, the size. Droplets in dry air evaporate quickly, decrease and fall to the ground more slowly. Changing droplet size affects how it reacts to the flow of air masses and how quickly it stabilizes [6].

As regards the number of emitted drops, it appears from the work in [7] that the human body can generate up to 40,000 drops during sneezing, which when evaporated form droplets in the range $0.5 \div 12 \mu \mathrm{m}$ in diameter. During a cough, an average of 3000 drops are excreted from the mouth, which corresponds to the number of particles exhaled during a speech lasting $5 \mathrm{~min}$. The size of the droplet is not significantly influenced by age, gender, or individual, and discrepancies noted in scientific publications are observed between healthy and sick people. The respiratory droplet size range in healthy subjects is $0.1 \div 8 \mu \mathrm{m}$ and $0.05 \div 10 \mu \mathrm{m}$ in patients. For healthy individuals, the average size of speech exhaled air droplets is $0.1-12 \mu \mathrm{m}$ (literature data range from 0.1 to $500 \mu \mathrm{m}$ ) [12]. The average size of droplets secreted with a cough is in the range 0.1-16 $\mu \mathrm{m}$ (for patients $0.1-6 \mu \mathrm{m}$ ). The above data were confirmed in a publication [13] by distributing the respiratory droplets (exhaled during speech and coughing) to individual fractions according to the adopted size class. The data presented by the author of [13] show that, in the case of speech, more than $62 \%$ of the droplets present in the exhaled air were $<12 \mu \mathrm{m}$ in diameter and more than $70 \%$ are in the $2-20 \mu \mathrm{m}$ range. With regard to respiratory droplets present during coughing, droplets with a diameter of $<12 \mu \mathrm{m}$ represent $72.81 \div 78.17 \%$ of all emitted droplets. The authors of [14] presented results consistent with the above. The presented data show that in the air exhaled together with a cough, the highest concentration are the droplets with a diameter in the range of $0.35-2.5 \mu \mathrm{m}(350-2500 \mathrm{~nm})$. The concentration range of droplets in air during human respiration is $0.001-12 \mathrm{~cm}^{-3}$ (breathing), $0.001-1.2 \mathrm{~cm}^{-3}$ (speaking), and $0.001-5.5 \mathrm{~cm}^{-3}$ (coughing) [15].

Particles greater than $500 \mu \mathrm{m}$ generated by sneezing/coughing/speech fall to the ground in a few seconds [16]. Droplets of 50-200 $\mu \mathrm{m}$, which are significantly affected by gravity, fall as the flow velocity decreases [17]. The estimated airborne duration of particles up to $10 \mu \mathrm{m}$ (speech, coughing) can reach up to $3 \mathrm{~h}$ [18] according to data in the literature. More detailed results are illustrated in [19]. Laboratory tests on respiratory 
droplets emitted during speech $(16.0 \mu \mathrm{m})$ and coughing $(13.5 \mu \mathrm{m})$ (the estimated number of droplets in the test was between 947 and 2085) showed that $90 \%$ of large-sized droplets ( $>50 \mu \mathrm{m}$ in diameter) settled rapidly within $1 \div 2 \mathrm{~m}$ of the emission point. The authors proved that only $4-10 \%$ of the droplets remained suspended in the air (diameter less than $10 \mu \mathrm{m}$ ), and it took less than $0.1 \mathrm{~s}$ for a droplet to evaporate and reduce its diameter from $5 \div 10 \mu \mathrm{m}$ to $2 \mu \mathrm{m}$. In addition, studies have shown that more than $82 \%$ of particles (drops) were in the size range $0.74-2.12 \mu \mathrm{m}$, which may affect the transit of the virus in the air [19].

The information presented in [6] shows that in a windless situation, the droplets fall to the ground at a short distance from the emitter (the range does not exceed $1 \mathrm{~m}$ ), and in a situation where the flight path of the particles is slightly longer, the trajectory of their flight will already be at a height well below half a meter, falling towards the ground. At wind velocities between $4 \mathrm{kmh}^{-1}$ and $15 \mathrm{kmh}^{-1}$, saliva droplets can move over a distance of more than $6 \mathrm{~m}$ with a drop in concentration and size of droplets in the wind direction [11].

It is therefore advisable to maintain a social distance of around $2 \mathrm{~m}$ in order to reduce the risk of the disease spreading to people. This is based on the assumption that there is no air circulation around people. So far, it has not been investigated how air mass movements, relative humidity, and temperature affect the structure of the respiratory droplets that carry the SARS-CoV-2 virus and the distance and direction of transmission of these particles in the air stream. It should be borne in mind that the value of the social distance of $2 \mathrm{~m}$, as defined for social distancing, was estimated on the basis of research conducted for closed facilities (such as rooms, halls, offices, waiting rooms, stations), assuming that there is no air circulation around people [6]. Thus, in order to determine the real risk of coronavirus and/or virus concentrations in the surrounding environment, except for basic environmental factors, such as temperature or humidity, account must also be taken of the flow of air masses in the facility (ventilation), determining transport, and, importantly, the degree of dispersion of respiratory droplets in the air stream, which ultimately affects the virus concentration in the air.

The problem outlined above affects the mining sector to a large extent, where a complex network of mining excavations creates complex airflow routes and, thus, the effects of SARS-CoV-2 virus transmission among people working in underground mining, which are difficult to estimate.

The flow of dispersed fluid droplets in workings of the longwall is not yet thoroughly examined. The environment of a mine is very different from the conditions of research conducted so far, which usually relate to closed buildings or open spaces. The microclimate underground in the underground mine is characterized by the variability of air humidity, the flow of which is forced, among others, by fans installed on the main shafts. In addition, increasingly deeper mining operations contribute to an increase in temperature in underground excavations, which, in turn, forces the use of air conditioning to improve the thermal comfort for miners. It is therefore advisable to carefully analyze the behavior of aerosols under such specific environmental conditions.

Ansys-CFX and Ansys-Fluent software using CFD (computational fluid dynamics) were selected to conduct numerical simulations.

\section{Materials and Methods}

\subsection{Laboratory Rig}

An object in the form of a section of an underground excavation located at a depth of $30 \mathrm{~m}$ was selected for research. The analyzed excavation site was separated from the ventilation network of the Experimental Mine Barbara (EM Barbara). EM Barbara is a part of the research and development infrastructure of the Central Mining Institute. The underground excavation is located close to the inhalation shaft (Barbara shaft) between the main pavement west and the ventilation pavement. The excavation is separated from pavements by two ventilation dams marked with $T_{2}$ and $T_{3}$ symbols. The $T_{2}$ dam regulates the value of air flows at the inlet to the underground excavation. The $T_{3}$ ventilation dam is an element of air control at the outlet from the excavation. 
The cross-section of the underground excavation at $5.8 \mathrm{~m}$ wide and $3.8 \mathrm{~m}$ high is $17 \mathrm{~m}^{2}$. The excavation consists of a yielding arch support size $Ł P 10$ made of a " $\mathrm{V}$ " section, built at a distance of $1.0 \mathrm{~m}$. The lining of the excavation filling the space between the rock mass (the excavation) and the arch support ŁP10 along the whole outline is made of reinforced concrete mine linings. Figure 1 shows a schematic representation of the position of the underground excavation in the ventilation network of the Barbara mine.

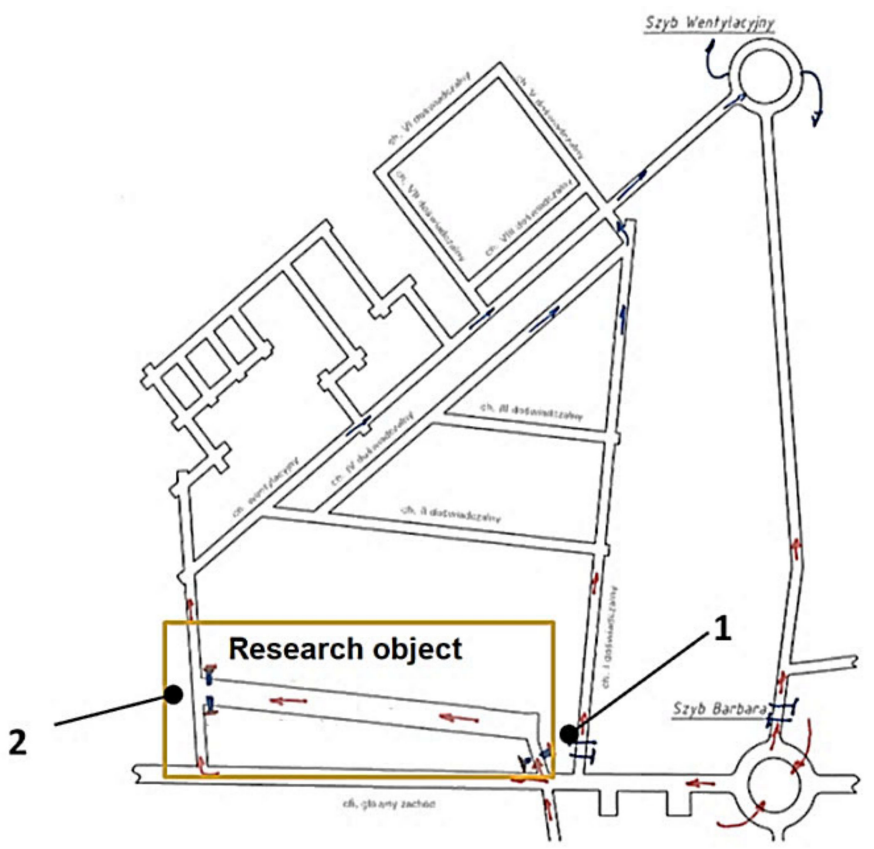

Figure 1. Location of the excavation in the ventilation network of the Experimental Mine Barbara: $1-$ dam $\mathrm{T}_{2}, 2-$ dam $\mathrm{T}_{3}$.

The following set of equipment was located in the analyzed section of the excavation for the purpose of testing the transport of dispersed fluid (aerosol) droplets in the air stream:

- A water nozzle to produce a dispersed phase of fluid droplets;

- A set of devices for measuring aerosol in the air stream in the form of scanning mobility particle sizer (SMPS) spectrometer 3936 and aerodynamic particle sizer (APS) spectrometer 3321.

The Spectrometer SMPS 3936 is a high-resolution nanoparticle sizer that was used to measure particle size in the air ventilating of the analyzed part of the underground excavation. The Spectrometer APS 3321 is a high-resolution and real-time aerodynamic sizer that was used to provide measurements of airborne particles from 0.5 to 20 microns [20,21].

A detailed diagram of the test stand and how the in situ tests were conducted is shown in Figure 2. The aerosol source was a water nozzle located about $25 \mathrm{~m}$ from the inlet (inlet) of the excavation. The water nozzle used ensured the generation of fluid droplets distributed to the volume limited by the shape of a full cone, which had a nozzle opening at its starting point and outlet. Spectrometers were located at a distance of $10 \mathrm{~m}, 25 \mathrm{~m}$, and $50 \mathrm{~m}$ from the nozzle that recorded the distribution of aerosol concentration changes in the air stream. Measurements were taken at four points of the cross-sectional area of the underground excavation at heights of $0.65 \mathrm{~m}$ and $1.55 \mathrm{~m}$ above the floor, as well as at the left and right sides of the excavation edge at the height of $1.55 \mathrm{~m}$ above the floor. The measurement was carried out for $3 \mathrm{~min}$, during which aerosol was injected continuously into the underground excavation. 


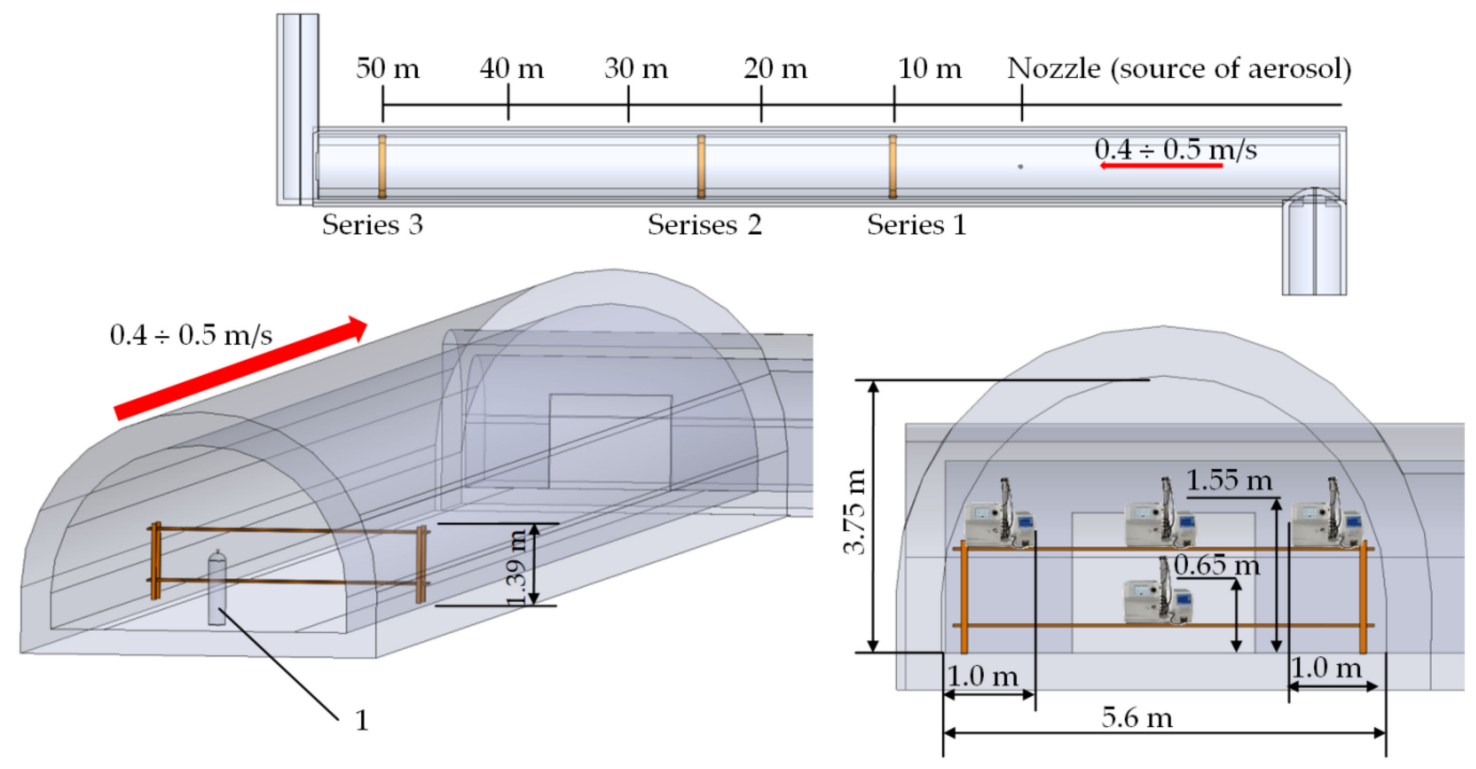

Figure 2. Schematic diagram of the laboratory rig and the aerosol measurement manner in the experimental part of the underground excavation: 1-nozzle (source of aerosol).

Figure 3 presents the actual view of the aerosol measurement station in the mixture of air and water vapor in the cross-section of the underground excavation selected for testing.

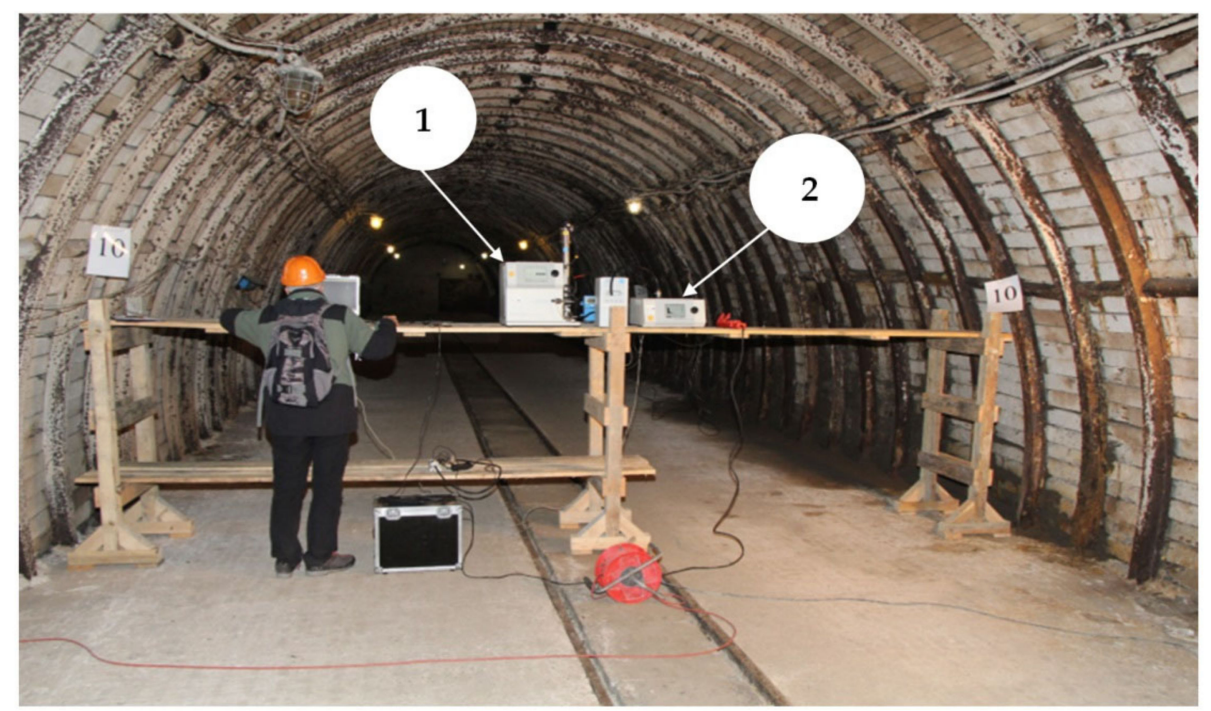

Figure 3. View of laboratory rig in the underground experimental excavation: 1 -Spectrometer SMPS 3936; 2-Spectrometer APS 3321.

The environmental conditions in the excavation during the research were:

- The temperature of the air $(\mathrm{T})$ entering the excavation ranged from 11 to $13^{\circ} \mathrm{C}$;

- Relative humidity $(\mathrm{RH})$ along the excavation under investigation varied between $83 \%$ and $90 \%$.

Prior to the tests of aerosol flow in the air stream ventilating the underground excavation, the concentration of natural aerosols carried in the stream of air and water vapor mixture. After the determination of the natural background, the relevant research was started, which was divided into three stages: 
- Stage I, marked as "series 1" in Figure 2, consisted of measuring changes in the concentration of aerosol droplets at a distance of $10 \mathrm{~m}$ from the nozzle $(35 \mathrm{~m}$ from the inlet to the excavation) within $3 \mathrm{~min}$;

- Stage II, marked as "series 2" in Figure 2, consisted of measuring changes in the concentration of aerosol droplets at a distance of $25 \mathrm{~m}$ from the nozzle $(50 \mathrm{~m}$ from the inlet to the excavation) within $3 \mathrm{~min}$;

- Stage III, marked as "series 3" in Figure 3, consisted of measuring changes in the concentration of aerosol droplets at a distance of $50 \mathrm{~m}$ from the nozzle $(75 \mathrm{~m}$ from the inlet to the excavation) within $3 \mathrm{~min}$.

Table 1 presents the actual results of changes in the morphology of aerosol particles raised in the air stream that ventilated the examined section of the excavation for a base case with and without the generation of aerosols.

Table 1. The percentage of individual fractions of drops in the total concentration.

\begin{tabular}{cccc}
\hline Aerosol Generation & Particle Class & Size Range $(\mathbf{n m})$ & Concentration $\left(\mathbf{T}_{\text {ave }}=\mathbf{1 2 . 5}{ }^{\circ} \mathbf{C}, \mathbf{R H}_{\text {ave }}=\mathbf{8 6} \%\right)(\mathbf{\%})$ \\
\hline \multirow{2}{*}{ YES } & Ultra-fine & $15-100$ & 79.4 \\
& Fine & $100-2500$ & 20.5 \\
& Coarse & $2500-19,810$ & 0.1 \\
\hline \multirow{2}{*}{ NO } & Ultra-fine & $15-100$ & 73.5 \\
& Fine & $100-2500$ & 26.5 \\
& Coarse & $2500-19,810$ & 0.0 \\
\hline
\end{tabular}

$\mathrm{T}_{\text {ave }}$-average temperature, $\mathrm{RH}_{\text {ave }}$-average relative humidity.

\subsection{CFD Method}

The first stage of numerical modeling using CFD methods was to define its purpose, i.e., to consider physical phenomena, conditions for the unambiguous solution for the numerical model and size of the calculation area. The second stage was to develop a geometry that reflected the real test object. After the creation of the geometric model, the next stage was discretization, i.e., generating a numerical grid, which is the area of numerical calculation of the analyzed issue. The last stage of the CFD modelling process was to properly define the boundary conditions for the problem under investigation (solver) and to perform numerical calculations with ongoing monitoring of the convergence of the obtained numerical solution.

\subsubsection{Assumptions}

The creation of a numerical model required a detailed definition of all physical parameters and quantities. Modeling the aerosol transport through a section of the mine workings separated from the ventilation network, based on CFD methods, requires knowledge of geometry (spatial model). In particular, it is necessary to know the length of the excavation and the shape of its cross-sections. It is optimal to use drawings of excavations developed in appropriate computer aided design (CAD) software. It was proposed that preliminary simulations should be carried out before the proper course of calculations was started, allowing for the assessment of the correctness of the developed numerical model. On the basis of this simulation, it was necessary to determine the correctness of the discretization of the spatial model and the adopted ways of taking turbulence into account. Obtaining satisfactory results of the simulation allows for concluding that the developed numerical model is suitable for use in the process of simulating the transport of dispersed particles of fluid droplets in the air stream.

The simulation of transport of dispersed fluid droplets using CFD methods comes down to solving a set of differential equations that represent the law of mass, momentum, and energy conservation in a finite volume of a fluid. The complexity of the flowing fluid behavior in the model fluid geometry is expressed by the following relationships [22,23]: 
- The mass conservation equation:

$$
\frac{\partial \rho}{\partial t}+\nabla \cdot(\rho \vec{v})=0
$$

- The momentum conservation equation:

$$
\frac{\partial}{\partial t}(\rho \vec{v})+\nabla \cdot(\rho \vec{v} \vec{v})=-\nabla p+\nabla \cdot(\widetilde{\tau})+p \vec{g}+\vec{F}
$$

- The energy conservation equation:

$$
\frac{\partial}{\partial t}(\rho E)+\nabla(\vec{v}(\rho E+p))=\nabla\left(k_{e f f} \nabla T-\sum h_{j} \vec{J}_{j}+\left(\widetilde{\tau}_{e f f} \cdot \vec{v}\right)\right)+S_{h}
$$

The influence of the occurring disturbances in the process of fluid transfer, in the space of a given geometry, was interpreted by the $k-\varepsilon$ turbulence model. The use of the $\mathrm{k}-\varepsilon$ turbulence model can be considered in the case when the level of accuracy can be acceptable and tolerated in simulation [20]. The solution of this model is to determine the value of turbulence viscosity, $\mu_{t}$, using the kinetic energy, $\mathrm{k}$, and the dissipation rate, $\varepsilon$, associated with the energy dissipation caused by the occurrence of internal movement resistance of the flowing fluid along the underground excavation. The viscosity model of the turbulence, $\mu_{t}$, of a flowing fluid is expressed by an equation defined in the following form [23-25]:

$$
\mu_{t}=\rho C_{\mu} \frac{k^{2}}{\varepsilon}
$$

The equations of fluid transport for the kinetic energy of turbulence, $k$, and dissipation, $\varepsilon$, are expressed in the form $[23,24]$ :

- For the kinetic energy of turbulence:

$$
\frac{\partial \rho k}{\partial t}+\frac{\partial \rho k v_{i}}{\partial x_{i}}=\frac{\partial}{\partial x_{i}}\left(\left(\mu+\frac{\mu_{i}}{\sigma_{k}}\right) \frac{\partial k}{\partial x_{i}}\right)+\tau_{i j}^{R} \frac{\partial v_{i}}{\partial x_{j}}-\rho \varepsilon+\mu_{t} P_{B}
$$

- For the energy of dissipation:

$$
\frac{\partial \rho k}{\partial t}+\frac{\partial \rho \varepsilon v_{i}}{\partial x_{i}}=\frac{\partial}{\partial x_{i}}\left(\left(\mu+\frac{\mu_{i}}{\sigma_{k}}\right) \frac{\partial \varepsilon}{\partial x_{i}}\right)+C_{\varepsilon 1} \frac{\varepsilon}{k}\left(f_{1} \tau_{i j}^{R} \frac{\partial v_{i}}{\partial x_{j}}+C_{B} \mu_{t} P_{B}\right)-f_{2} C_{\varepsilon_{2}} \frac{\rho \varepsilon^{2}}{k}
$$

The model of fluid droplet evaporation in Ansys-CFX was expressed as a model of particles with heat transfer and mass transfer component in which a continuous gaseous phase has a higher temperature than the particles. The model uses two mass transfer correlations depending on whether the drop is above or below the boiling point. This is defined by a formula expressed as follows [24]:

$$
p_{\text {vap }}=p_{\text {ref }} \exp \left(A-\frac{B}{T+C}\right)
$$

Equation (7) describes the relationship between vapor pressure and fluid temperature. The temperature of the aerosol is analyzed in accordance with the heat balance (3), which binds the heat change in the droplet to the convective and latent heat transfer between the drop and the continuous phase, i.e., the mixture of air and water vapor. If the vapor pressure $p_{v a p}$ is greater than the ambient gas pressure, the particle is boiling [24].

In Ansys-Fluent, the droplet vaporization model is defined by a formula expressed as follows [23]:

$$
T_{\text {vap }} \leq T_{p}<T_{b p}
$$


Equation (8) describes the vaporization relationships from a discrete phase droplet under the conditions when the droplet in the continuous phase (air) reaches the temperature of vaporization and continues at the moment when the droplet reaches the boiling point and is completely consumed.

In order to carry out numerical calculations, the following boundaries conditions for the unambiguous solution of the numerical model should be considered:

1. For a given numerical model of the excavation (fluid model):

- Temperature of independent air flowing into the excavation;

- Air volume flow rate;

- Roughness of the excavation;

- Heat conduction coefficient, density, and specific heat of the material surrounding the excavation.

2. For a given model of aerosol emitter (nozzle model):

- Coordinates of the position of the nozzle opening;

- Density of aerosol droplets;

- Diameter of aerosol droplets (morphology);

- Aerosol specific heat;

- Droplet outflow rate;

- Droplet conductivity.

An important stage in conducting the simulation is to consider the global conditions of the solution, namely:

- Defining the nature of the simulated phenomenon (unstable or steady state);

- Air pressure;

- Nature of the air flowing (turbulent or laminar);

- Timescale;

- Required convergence of numerical calculations.

\subsubsection{Numerical Grid}

In the case of aerosol emissions in the ventilation network of a deep mine, the volume of the excavation defined by its cross-sectional area is crucial. This parameter directly determines the value of the air stream flowing through the given section of the excavation and, thus, influences the velocity of aerosol distribution and transport on the given length of the excavation.

For the purposes of the work, it was assumed that the shape of the excavation will be mapped by the arch support type ŁP10, with the main geometric dimensions listed in Table 2. The ŁP10 arch support is an actual element of the support used in the discussed underground excavation.

Table 2. Dimensions of the three-piece yielding arch support type $Ł P 10$ [25].

\begin{tabular}{ccccccccc}
\hline Dimensions & $\mathbf{W}$ & $\mathbf{H}$ & $\mathbf{C}_{\mathbf{1}}$ & $\mathbf{C}_{\mathbf{2}}$ & $\mathbf{A}_{\mathbf{1}}$ & $\mathbf{A}_{\mathbf{2}}$ & $\mathbf{k}$ & $\mathbf{e}$ \\
\hline $\begin{array}{c}\text { Arch support } \\
\text { ŁP10 }\end{array}$ & 5500 & 3800 & 3075 & 2700 & 3170 & 3170 & 870 & 600 \\
\hline
\end{tabular}

Figure 4 shows an overview drawing of the main dimensions of the arch support type ŁP10. 


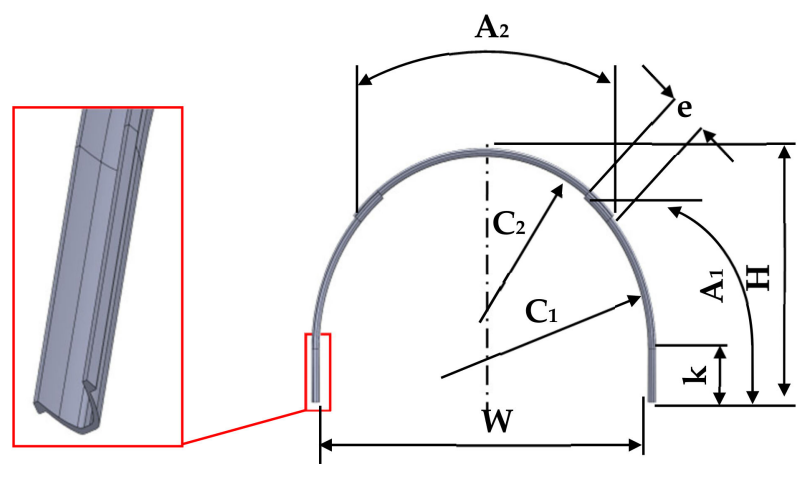

Figure 4. An overview drawing of the basic dimensions of the arch support type 10.

Using the possibilities and functionality of the software used, a solid model of the excavation was developed to create a numerical grid, and the effects of the actions taken are presented in Figure 5.

a)

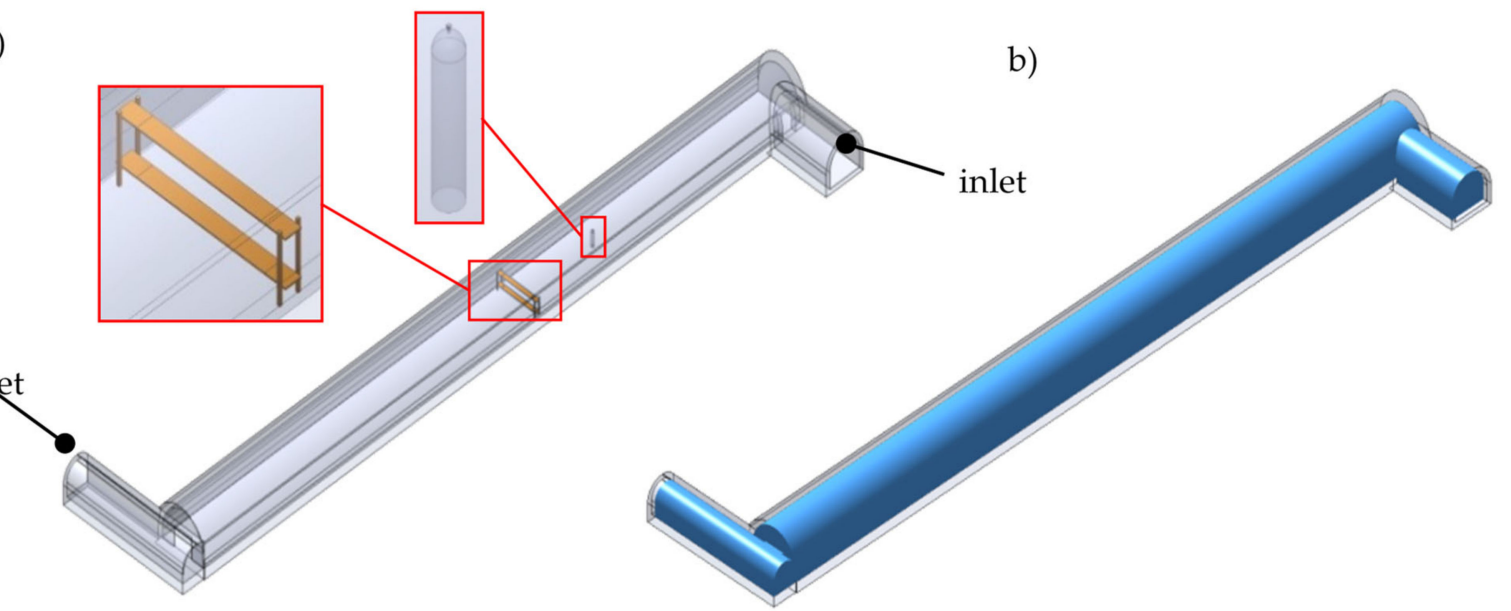

Figure 5. Geometric model of the tested excavation: (a) spatial model; (b) separated volume of the fluid.

The geometrical model presented in Figure 5, $80 \mathrm{~m}$ long and with a cross-sectional area of $17 \mathrm{~m}^{2}$ (Figure 5a), is a representation of the real underground research object. On its basis, the volume of the fluid was separated (Figure $5 b$ ). The defined volume of the fluid filling the model excavation was discretized, i.e., the spatial model was divided into smaller finite volumes. Figure 6 presents the effects of discrediting the developed 3D model of the underground excavation.

In order to ensure that the results obtained from numerical calculations were adequate, the mesh density was considered before using the discretized geometry for simulation. Figure 6 illustrates the mesh refinement study on the volume flow rate results in the numerical model. Moreover, in order to ensure that the numerical grid was correct the following mesh quality was developed $[23,24]$ :

- The minimum orthogonal quality was $8.88147 \times 10^{-1}$, which meant that the mesh corresponded to a high quality;

- The maximum orthogonal skewness was $2.58533 \times 10^{-2}$, which meant that the mesh corresponded to a high quality. 


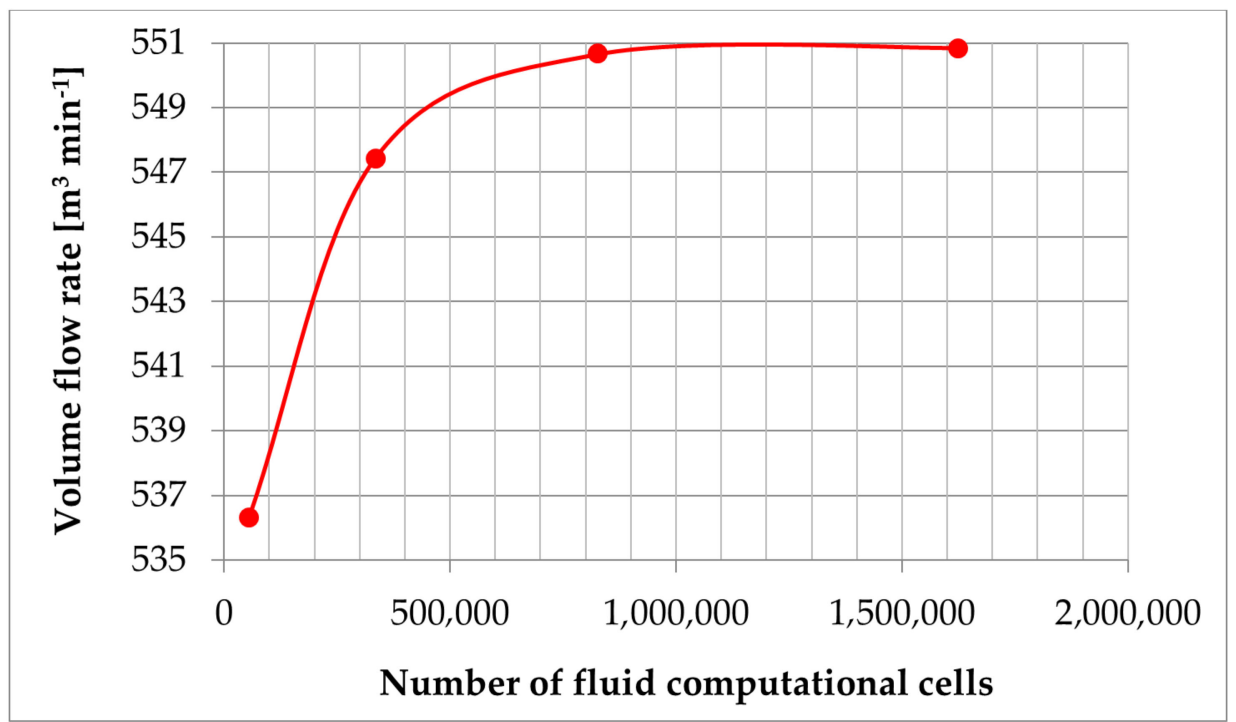

Figure 6. Convergence of results in the numerical grid refinement study.

In additional, the 12 inflation layers were considered and located within the boundary layer of flow to properly resolve the boundary layer as was shown in Figure 7.

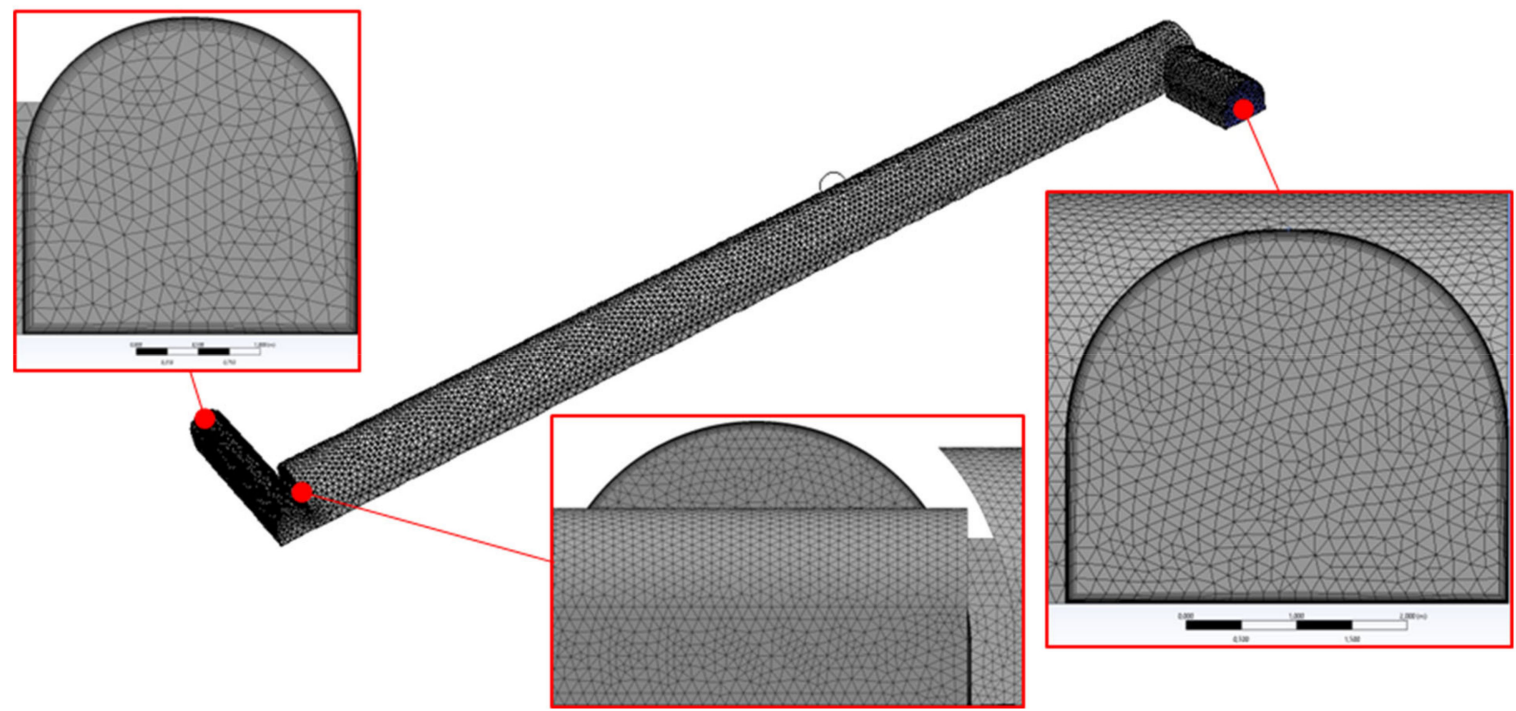

Figure 7. Numerical grid of the underground working.

The results of the four mesh densities were compared in Table 3.

Table 3. Results of numerical grid refinement study.

\begin{tabular}{cccc}
\hline Number & Mesh Quality & $\begin{array}{c}\text { Number of Fluid } \\
\text { Computational Cells }\end{array}$ & $\begin{array}{c}\text { Volume Flow } \\
\text { Rate ( } \mathbf{m}^{\mathbf{3}} \mathbf{m i n}^{-\mathbf{1}} \text { ) }\end{array}$ \\
\hline 1 & coarse & 55,712 & 536.34 \\
2 & normal & 335,418 & 547.45 \\
3 & fine & 826,397 & 550.65 \\
4 & very fine & $1,625,445$ & 550.85 \\
\hline
\end{tabular}

The volume flow rate of fluid was measured at the outlet. It can be observed in Table 3 that the coarse and normal mesh forecast less accurate volume flow rates, but the fine and very fine mesh forecast similar results. In this case, a decision was made that 
the mesh in the numerical model would contain above the 826,397 computational cells according to the convergence study results. The value of refinement in Figure 7 was the result of grid sensitivity analysis, where the solver improved and refined the mesh of the longwall panel without active user intervention during the numerical calculations. The numerical grid of the excavation (Figure 7) was formed from 826,397 elements jointed with 156,455 nodal points.

\section{Results}

The results of numerical simulations of the aerosol transport process carried out for a specific value of the air stream flowing through the analyzed section of the underground excavation are presented below. The following boundary conditions of the numerical solution for the model system under test were included:

- Average temperature- $-12^{\circ} \mathrm{C}$;

- Volume flow rate of the air at the inlet $-551 \mathrm{~m}^{3} \mathrm{~min}^{-1}\left(9.18 \mathrm{~m}^{3} \mathrm{~s}^{-1}\right)$;

- Relative roughness of the walls- $0.1 \mathrm{~m}$;

- The continuous phase was a mixture of air and water vapor as an ideal gas;

- Aerosol particles were pure water,

- Sizes of modeled droplet fractions (10,000 nm, 20,000 nm, 30,000 nm, 40,000 nm, $50,000 \mathrm{~nm}, 60,000 \mathrm{~nm}, 70,000 \mathrm{~nm}, 80,000 \mathrm{~nm}, 90,000 \mathrm{~nm}, 100,000 \mathrm{~nm}, 110,000 \mathrm{~nm}$, and $120,000 \mathrm{~nm})$;

- Air density: $1.2 \mathrm{kgm}^{-3}$;

- Gravity: $9.81 \mathrm{~ms}^{-2}$;

- Turbulence model: k-ع;

- Heat transfer model for particles;

- $\quad$ Air heat transfer model;

- $\quad$ Particle coupling model, i.e., the mixture of air and water vapor acts on the aerosol and the aerosol acts on the mixture;

- $\quad$ Friction force at the air/aerosol interface (drag force);

- Aerosol velocity injection-150 $\mathrm{ms}^{-1}$;

- Droplets were evaporated in a stream of air;

- $\quad$ Average temperature of the injected aerosol: $12{ }^{\circ} \mathrm{C}$;

- $\quad$ The number of droplets of each aerosol: 100 drops per second;

- Average relevant humidity: $86 \%$;

- $\quad$ Average pressure: 97,800 Pa.

Figure 8 shows the distribution of air volume flow changes, which reflects the actual ventilation conditions prevailing in the analyzed section of the underground excavation. The inlet to the excavation was located in front of the $\mathrm{T}_{2}$ dam. The outlet was located in the ventilation gallery, a short distance behind the $\mathrm{T}_{3}$ dam.

In the section of the given excavation study $80 \mathrm{~m}$ long, directly behind ventilation dam $\mathrm{T}_{2}$, the air volume flow rate was $551 \mathrm{~m}^{3} \mathrm{~min}^{-1}\left(\sim 0.55 \mathrm{~ms}^{-1}\right)$.

One of the first stages of the correctness of the conducted simulations was to relate the results of the numerical calculations of the velocity profile with the results of measurements that were measured in the course of the actual research. The actual values of changes in air velocity along the examined section of the excavation are presented in Table 4 . The predicted results for the air velocity profile at $50 \mathrm{~m}$ from the nozzle are shown in Figure 8 .

The analysis of the results in Figure 9 shows that at a distance of about $25 \mathrm{~m}$ from the nozzle (position 1 in Figure 8), the value of velocity in the cross-sectional area of the excavation reached the value of about $0.43 \mathrm{~ms}^{-1}$ at the left sidewall and about $0.36 \mathrm{~ms}^{-1}$ in the middle of the excavation. On the section of $50 \mathrm{~m}$ from the nozzle, the forecast value of air velocity on the left sidewall reached approximately $0.32 \mathrm{~ms}^{-1}$, in the middle of the excavation approximately $0.55 \mathrm{~ms}^{-1}$, while on the right sidewall it was approximately $0.50 \mathrm{~ms}^{-1}$. 


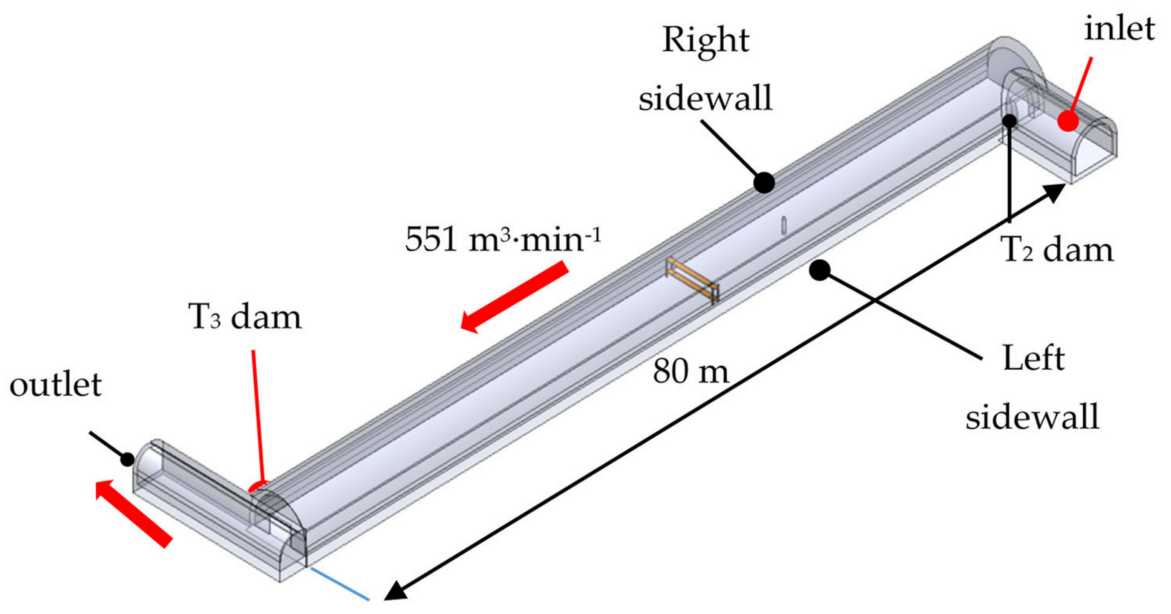

Figure 8. The distribution of the air volume flow in the excavation adopted in the numerical model.

Table 4. Values of air velocity in the examined excavation.

\begin{tabular}{cccc}
\hline Distance from the Nozzle & Left Sidewall & Center & Right Sidewall \\
\hline $0 \div 25 \mathrm{~m}$ & 0.43 & 0.35 & 0.38 \\
$50 \mathrm{~m}$ & 0.30 & 0.50 & 0.50 \\
Ventilation shaft & 1.84 & 2.00 & 2.05 \\
\hline
\end{tabular}

a)

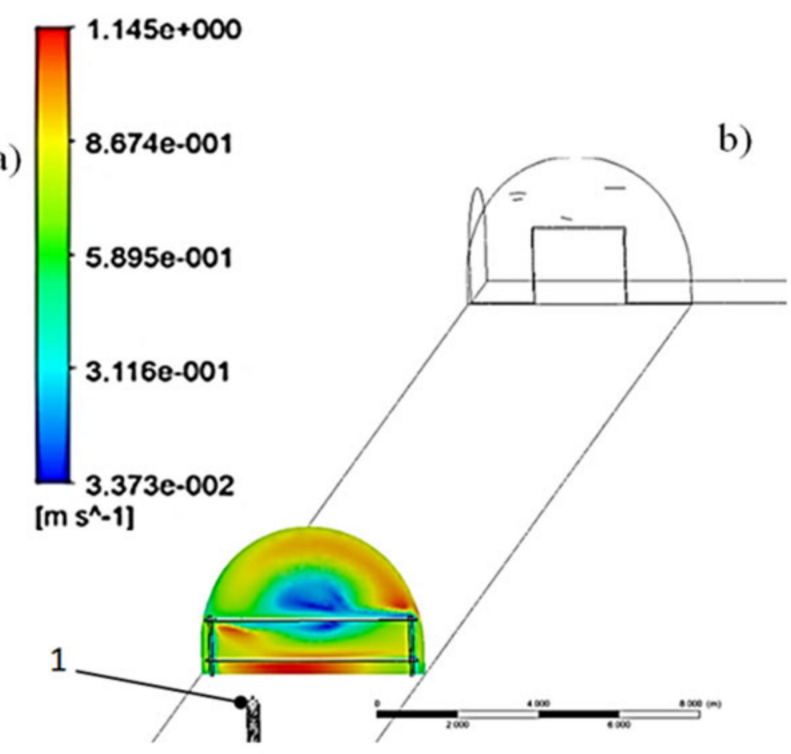

c)
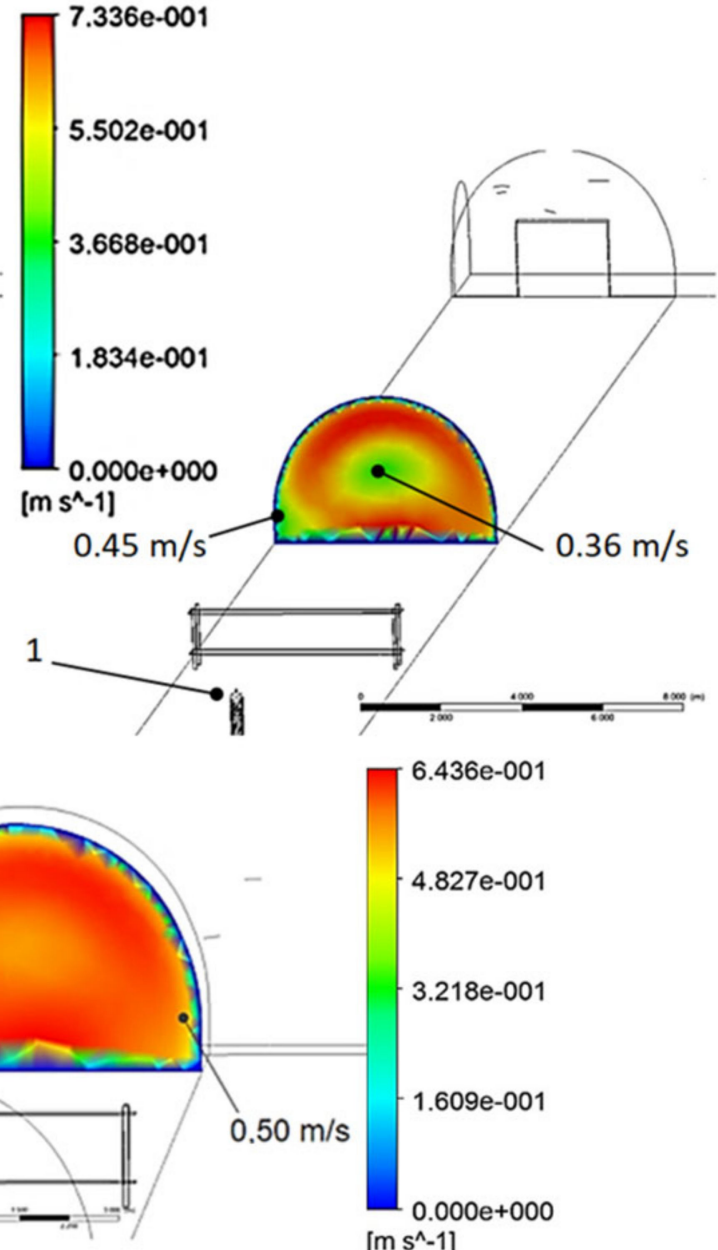

Figure 9. Air velocity in the cross-section of the excavation: (a) $10 \mathrm{~m}$ from the nozzle, (b) $25 \mathrm{~m}$ from the nozzle, (c) $50 \mathrm{~m}$ from the nozzle, 1 -water nozzle. 
In order to additionally verify the results of the obtained numerical solution, it was decided to analyze the distribution of air velocity over the entire section of the developed model of the underground excavation. The results of the qualitative analysis are presented in Figure 10 in the form of a graphic map.

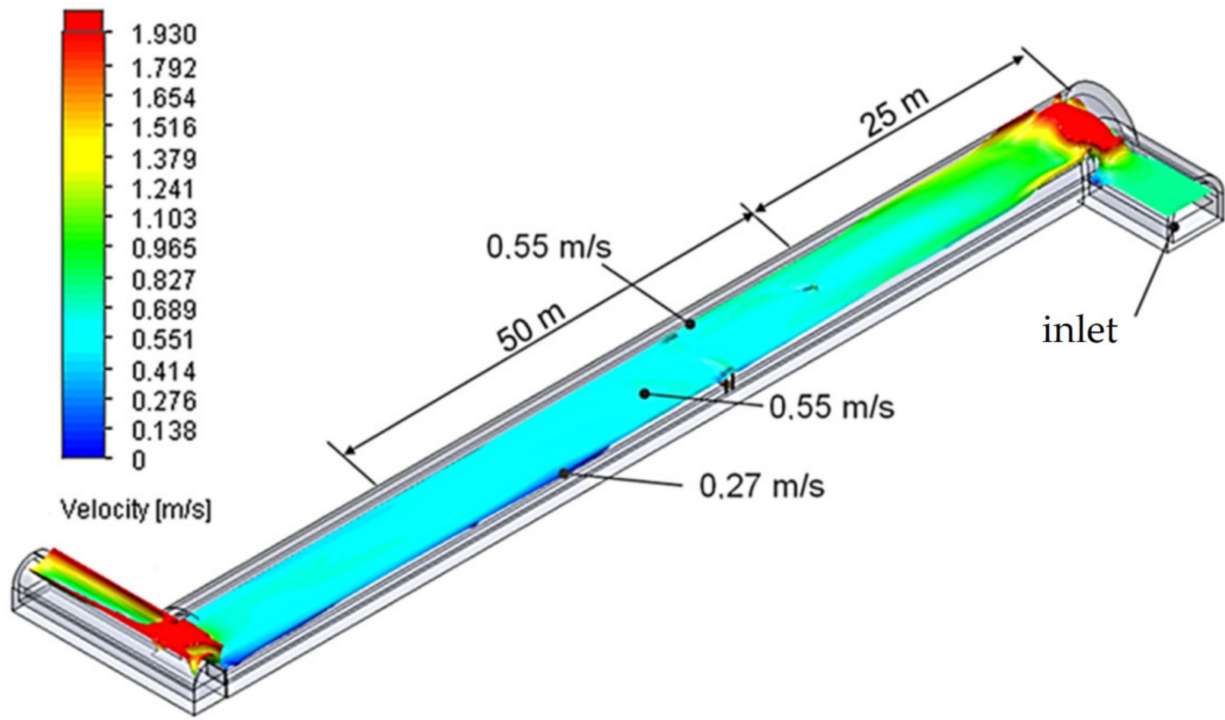

Figure 10. Air velocity along the underground excavation.

The analysis of the distribution of air velocity changes in the horizontal plane of the excavation shows that at a distance of about $50 \mathrm{~m}$ from the nozzle, in the axis of the excavation, the velocity reached a value of approximately $0.55 \mathrm{~ms}^{-1}$. In the vicinity of the sidewalls, however, the air velocity decreased to approximately $0.27 \mathrm{~ms}^{-1}$. In the section of the ventilation shaft, directly behind the $T_{3}$ ventilation dam, in the vicinity of the longwalls and in the axis of the excavation, the recorded value of air velocity was approximately $1.96 \mathrm{~ms}^{-1}$.

Additionally, Figure 11 presents the analysis of the trajectory of the flowing ventilation airline that was performed for the given conditions of the excavation geometry. The qualitative analysis showed the occurrence of significant air turbulence in the axis of the excavations, which was observed on a section at the length of $35 \mathrm{~m}$ from the inlet side.

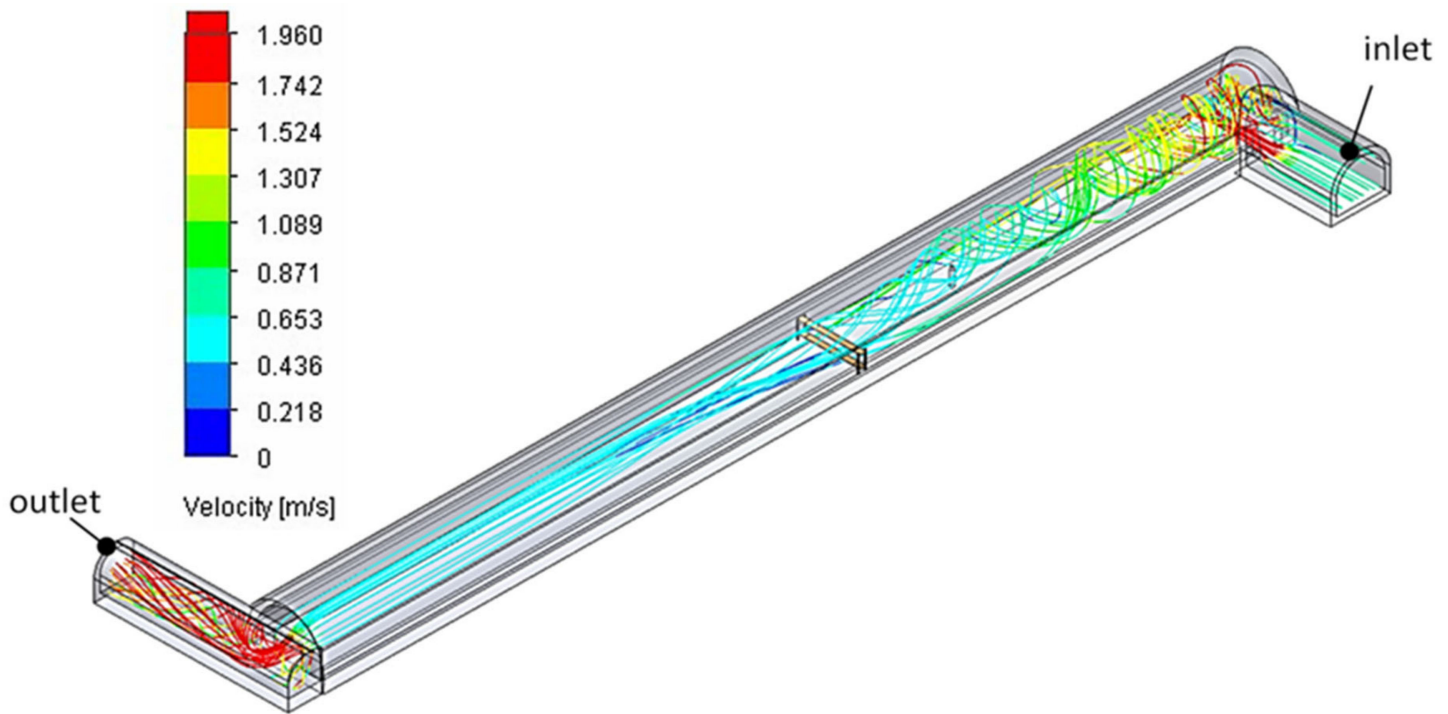

Figure 11. The trajectory of air flowing through the analyzed excavation. 
Table 5 compares the results of measuring the air velocity in the excavation site during in situ tests with the results of model tests.

Table 5. Results of air velocity measurements during in situ tests and from the CFD calculations.

\begin{tabular}{|c|c|c|c|c|c|c|c|c|c|}
\hline \multirow{2}{*}{$\begin{array}{l}\text { Distance from } \\
\text { Nozzle }\end{array}$} & \multicolumn{3}{|c|}{ In Situ Tests } & \multicolumn{3}{|c|}{ CFD } & \multicolumn{3}{|c|}{ Relative Error $\Delta \delta$} \\
\hline & $\begin{array}{c}\text { Left } \\
\text { Sidewall }\end{array}$ & $\begin{array}{c}\text { Middle } \\
\text { Aera }\end{array}$ & $\begin{array}{c}\text { Right } \\
\text { Sidewall }\end{array}$ & $\begin{array}{c}\text { Left } \\
\text { Sidewall }\end{array}$ & $\begin{array}{c}\text { Middle } \\
\text { Aera }\end{array}$ & $\begin{array}{c}\text { Right } \\
\text { Sidewall }\end{array}$ & $\begin{array}{c}\text { Left } \\
\text { Sidewall }\end{array}$ & $\begin{array}{c}\text { Middle } \\
\text { Aera }\end{array}$ & $\begin{array}{c}\text { Right } \\
\text { Sidewall }\end{array}$ \\
\hline $0-25 \mathrm{~m}$ & 0.43 & 0.35 & 0.38 & 0.45 & 0.36 & 0.45 & $4.4 \%$ & $2.8 \%$ & $15.6 \%$ \\
\hline $50 \mathrm{~m}$ & 0.30 & 0.50 & 0.50 & 0.27 & 0.55 & 0.55 & $10.0 \%$ & $9.1 \%$ & $9.1 \%$ \\
\hline Ventilation shaft & 1.84 & 2.00 & 2.05 & 1.96 & 1.96 & 1.96 & $6.1 \%$ & $2.0 \%$ & $4.4 \%$ \\
\hline
\end{tabular}

Comparing the actual test results with the numerical calculation values, a significant correlation can be observed between the CFD and in situ values, which makes it possible to conclude that the assumptions made and the input data for the numerical model were formulated correctly.

The last stage of the model tests was to compare the actual results of measurements of the distribution of aerosol particle size changes measured at a distance of $10 \mathrm{~m}, 25 \mathrm{~m}$, and $50 \mathrm{~m}$ from the nozzle with the results of the numerical calculations. Figure 12 shows the predicted distribution of changes in aerosol particle morphology along the model excavation. The horizontal axis of the graphs shows the length of the excavation. The vertical axis of the diagrams shows the values of changes in the diameter of droplet particles.
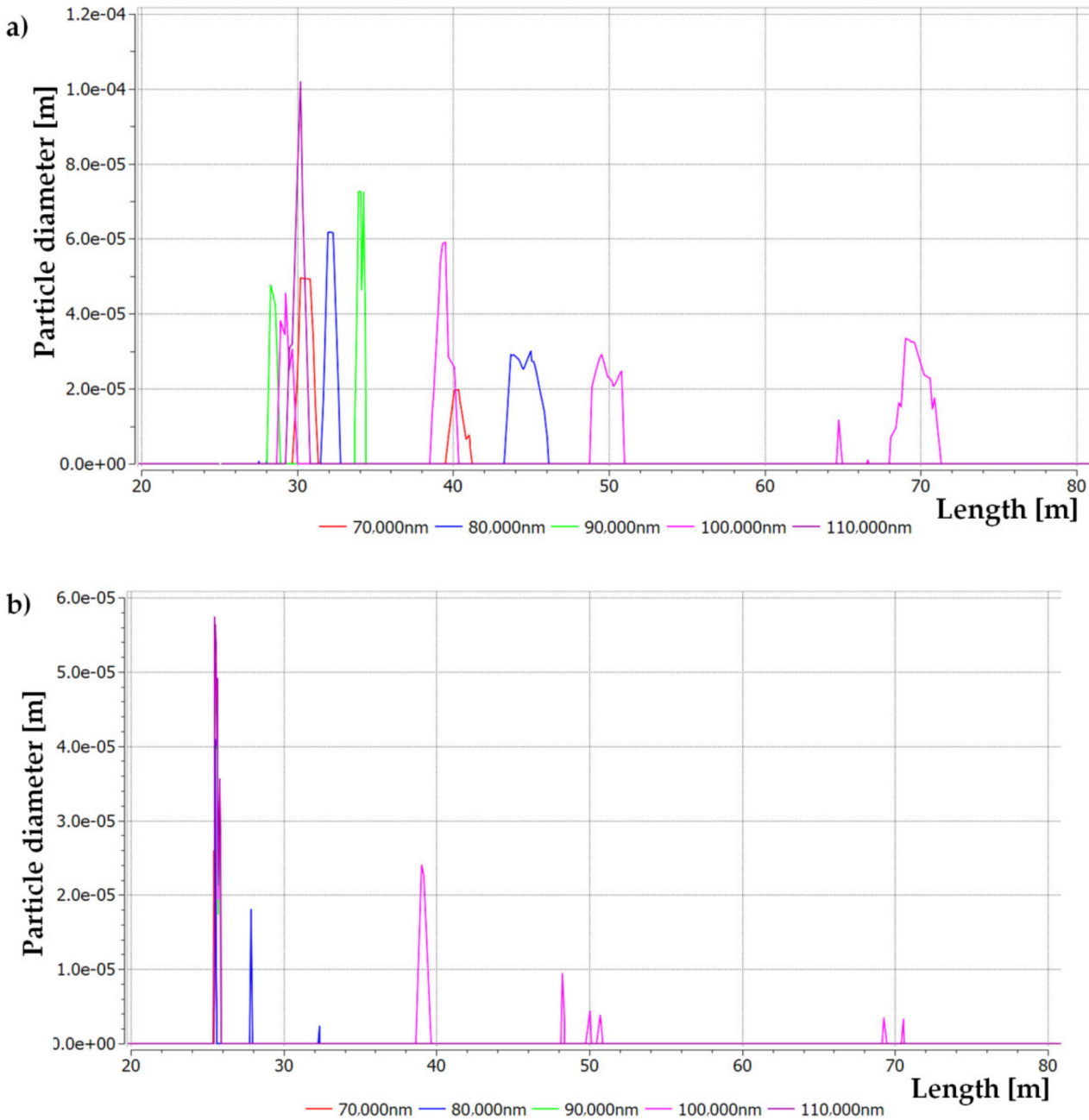

Figure 12. Cont. 

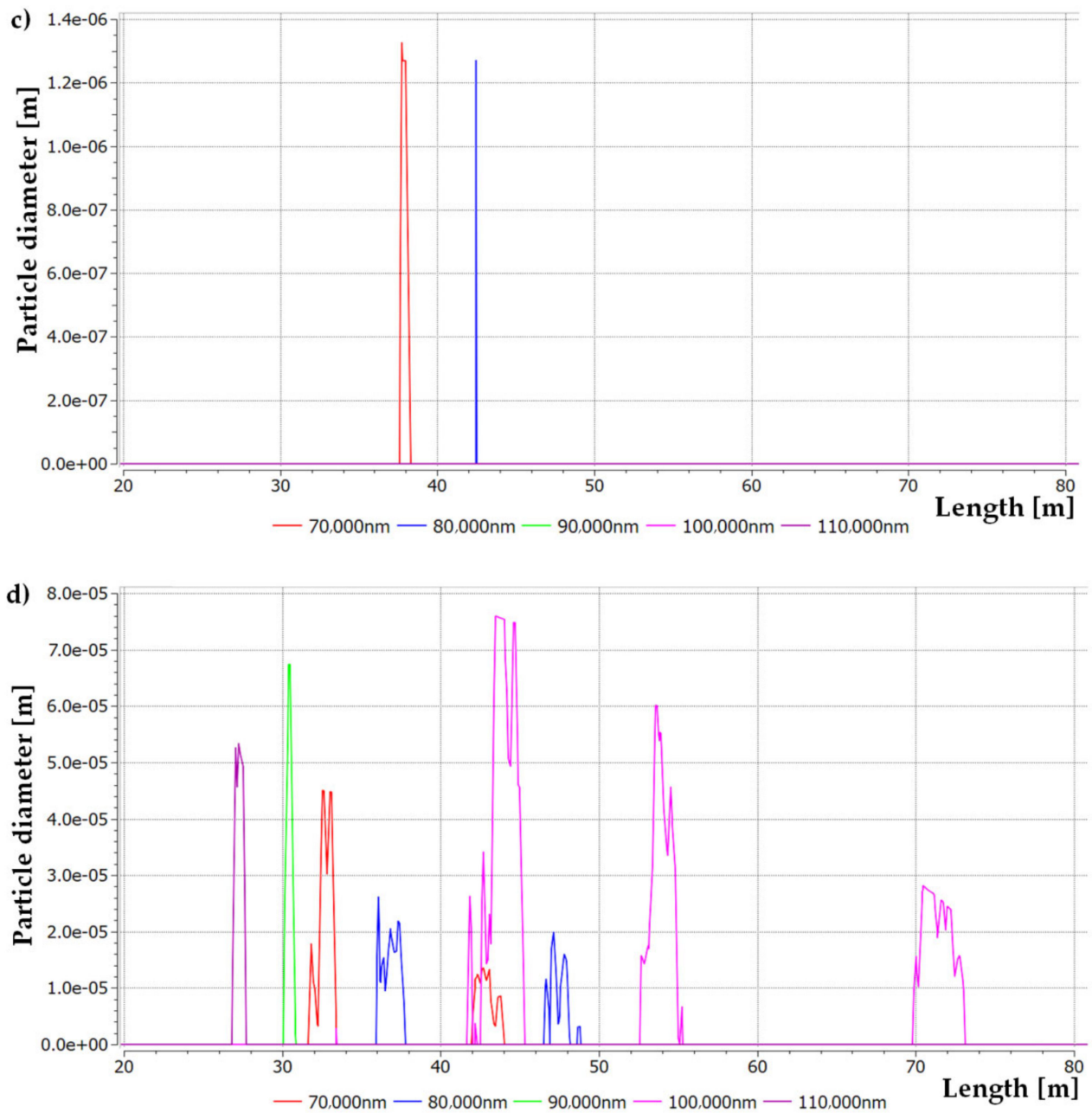

Figure 12. Forecasted distribution of aerosol droplet particle size changes depending on the length of the excavation at the following height: (a) $0.65 \mathrm{~m}$ above the floor, (b) $1.55 \mathrm{~m}$ above the floor, (c) $1.55 \mathrm{~m}$ above the floor at a distance of $1 \mathrm{~m}$ from the left aisle, and (d) $1.55 \mathrm{~m}$ above the floor at a distance of $1 \mathrm{~m}$ from the right sidewall.

The analysis of the graphs presented in Figure 12 shows an increase in the concentration of coarse aerosols at a height of $0.65 \mathrm{~m}$ above the floor. Initially, the increase takes place on the length of $30 \mathrm{~m}$ of the excavation ( $5 \mathrm{~m}$ from the nozzle), until complete evaporation

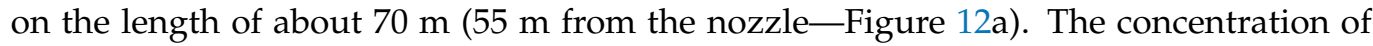
coarse aerosols in the axis of the excavation, at the height of $1.55 \mathrm{~m}$, increases between $20 \mathrm{~m}$ and $30 \mathrm{~m}$ of the length of the excavation ( $5 \mathrm{~m}$ from the nozzle-Figure $12 \mathrm{~b}$ ), after which a sharp decline was recorded. In the case of the left and right sidewalls of the excavation, a significant increase in the concentration of coarse aerosols was observed along the length of the excavation approximately $45 \mathrm{~m}$ ( $20 \mathrm{~m}$ from the nozzle), followed by their complete evaporation along the length of about $70 \mathrm{~m}$ ( $55 \mathrm{~m}$ from the nozzle-Figure 12d). It can be observed that on the right side, the increase in the concentration of aerosol droplets was higher compared to the left side.

In addition, Figure 13 presents graphs of changes in the range of a coarse aerosol with a diameter of up to $100 \mu \mathrm{m}$ obtained from the solved numerical model in Ansys-Fluent (Figure 13a) and Ansys-CFX (Figure 13b). The range of aerosol droplets was interpreted with the use of graphs showing the values of droplet diameter changes as a function of changes in the length of road (path) travelled by aerosol droplets on the analyzed length of a model underground excavation on the vertical axis. The change in the diameter of 
aerosol droplets was caused by the mechanism of evaporation (relation-(7) and (8)) of the aerosol in the flow of air and water vapor, which is included in the numerical model.
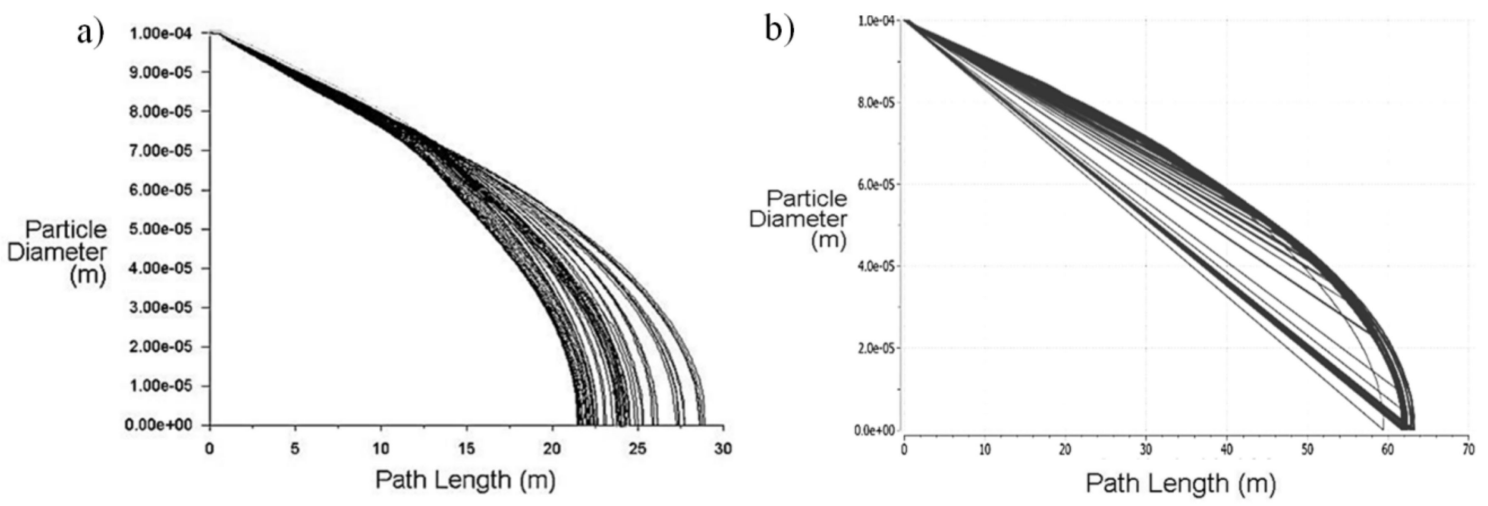

Figure 13. Predicted distribution of aerosol droplet changes $100 \mu \mathrm{m}$ in diameter obtained from the CFD model: (a) AnsysFluent, (b) Ansys-CFX.

Table 6 presents the comparison of the results of the path length measurements of $100 \mu \mathrm{m}$ droplets obtained during the in situ test and CFD simulations. It was observed that the path length of a droplet under the in situ conditions reached $50 \mathrm{~m}$ from the nozzle (Figure 15a), while the path length of a droplet during CFD simulations reached correspondingly: a distance of $30 \mathrm{~m}$ from the nozzle obtained from Ansys-Fluent calculations (Figure 13a) and a distance of $63 \mathrm{~m}$ from the nozzle obtained from Ansys-CFX calculations (Figure 13b).

Table 6. Results of the path length of aerosols during in situ tests and CFD calculations.

\begin{tabular}{ccc}
\hline In Situ & Ansys-Fluent & Ansys-CFX \\
\hline & Distance from the Nozzle (m) & \\
\hline 50 & 30 & 60 \\
\hline
\end{tabular}

It can be observed that the result of the numerical calculations obtained from AnsysCFX was closer to the in situ tests than the calculations obtained from the Ansys-Fluent. This was caused by setting the parameters of the evaporation model Equation (7) available in Ansys-CFX software. Whereas in Ansys-Fluent, the evaporation process was realized by solving a given imbalance in the form of an Equation (8). This means that the evaporation model in Ansys-CFX was formulated correctly.

Figure 14 shows the predicted trajectories of aerosol droplet movement depending on the diameter under considered temperature, humidity, and air pressure conditions: $50 \mu \mathrm{m}$ (Figure 14a), $60 \mu \mathrm{m}$ (Figure 14b), $70 \mu \mathrm{m}$ (Figure 14c), $80 \mu \mathrm{m}$ (Figure 14d), $90 \mu \mathrm{m}$ (Figure 14e), $100 \mu \mathrm{m}$ (Figure 14f), $110 \mu \mathrm{m}$ (Figure 14g), and $120 \mu \mathrm{m}$ (Figure 14h). Below the values of the given droplet diameters, the aerosol completely evaporated at the outlet of the nozzle. 
a)

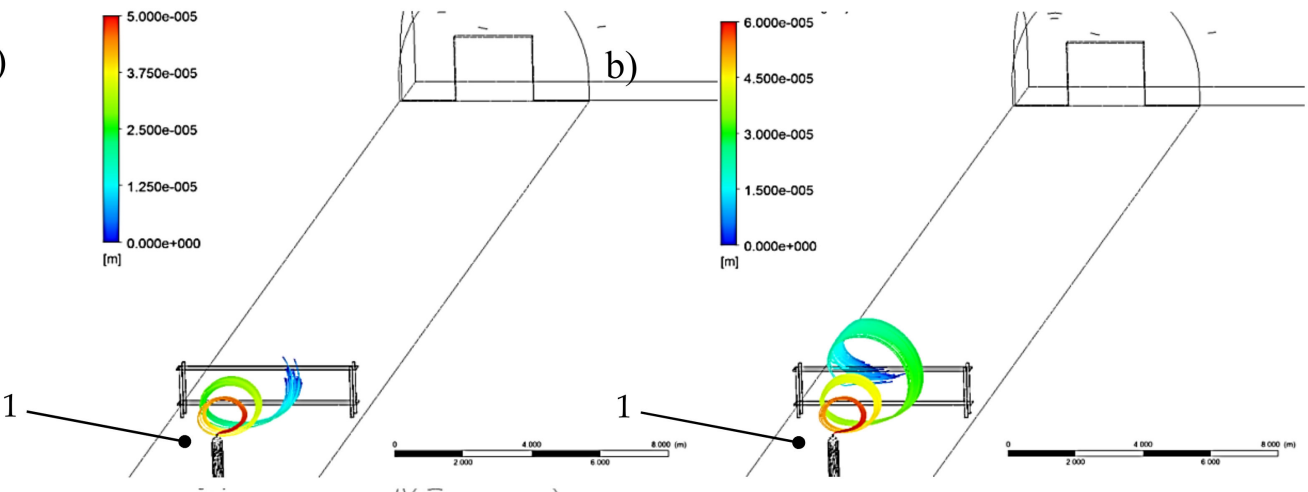

c)

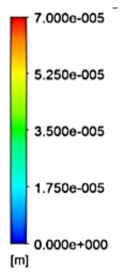

d) $\quad 0.0000-005$

\section{.}

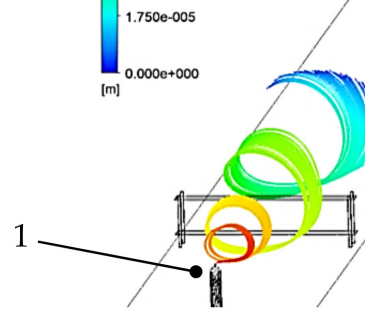

e)
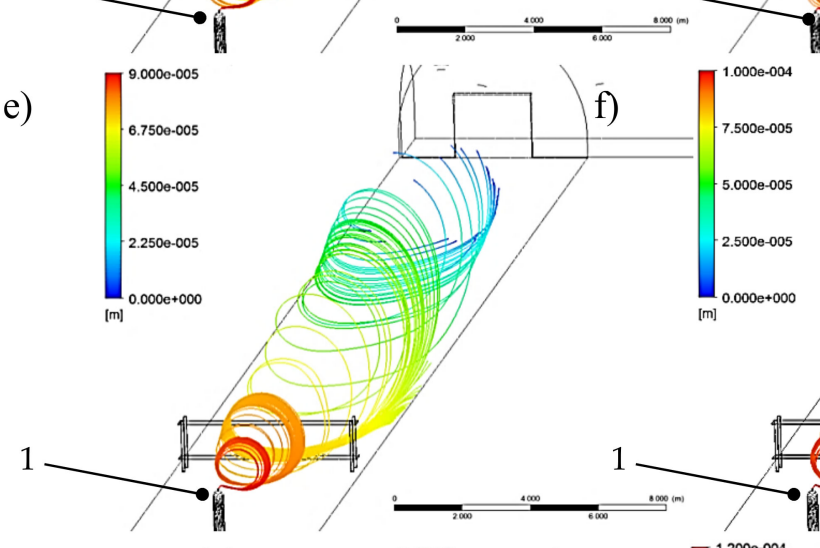

$\int_{2.0000-005}^{4.0000-005}$

g)
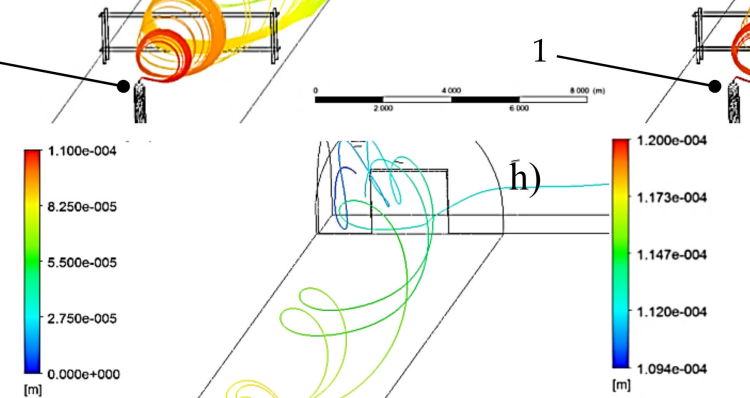

$=4$

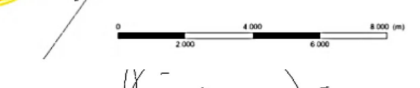


a)

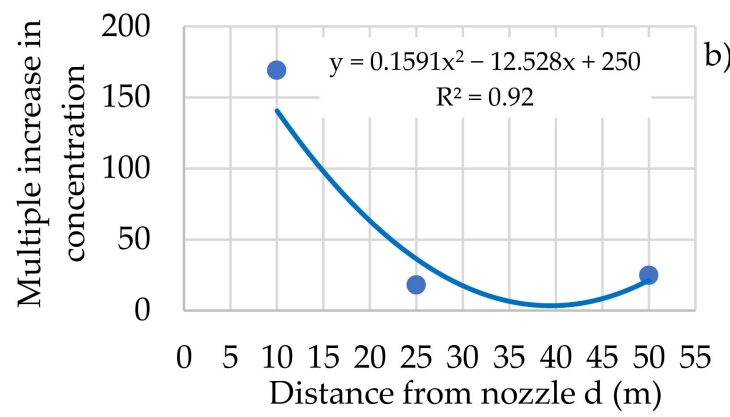

b)

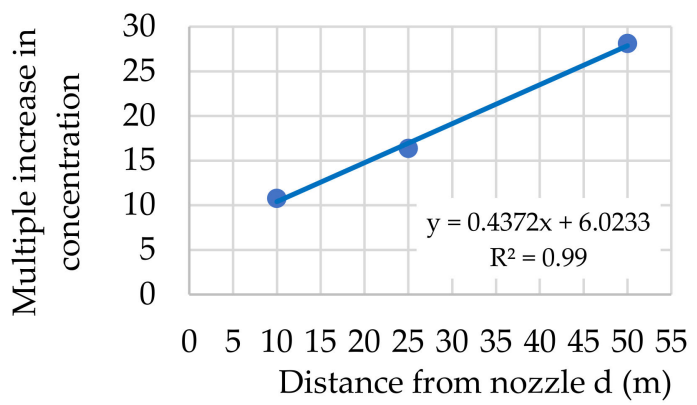

Figure 15. Distribution of changes in the concentration of coarse aerosols depending on the distance from the nozzle at the height above the floor: (a) $1.55 \mathrm{~m}$, (b) $0.65 \mathrm{~m}$.

The curves in Figure 15a show a decrease in the concentration of coarse aerosols in the excavation axis from a value of approximately 170 at a distance of $10 \mathrm{~m}$ from the nozzle (35 $\mathrm{m}$ from the inlet of the excavation) to a value of approximately 25 at a distance of $50 \mathrm{~m}$ from the nozzle ( $75 \mathrm{~m}$ from the inlet of the excavation) at a height of $1.55 \mathrm{~m}$ above the floor. In the case of measuring coarse aerosols at a height of $0.65 \mathrm{~m}$ above the floor (Figure 15b), actual measurement results showed an increase in the concentration multiplication factor from a value of about 11 , at the distance of $10 \mathrm{~m}$ from the nozzle ( $35 \mathrm{~m}$ from the inlet of the excavation) to the value of approximately 30 at the distance of $50 \mathrm{~m}$ from the nozzle $(75 \mathrm{~m}$ from the inlet of the excavation).

The concentration of coarse aerosols at the height above the floor $1.55 \mathrm{~m}$ depending on the distance from the source of injection for a given temperature, velocity, and humidity conditions of air can be predicted by the equation:

$$
\text { aerosol }_{\text {coarse }(1.55 m)}=0.1591 d^{2}-12.528 d+250
$$

In the case of the coarse aerosols at the height above the floor $0.65 \mathrm{~m}$, the concentration can be predicted by equation:

$$
\text { aerosol }_{\text {coarse }(0.65 m)}=0.4372 d+6.023
$$

Figure 16 shows the comparisons of changes in the concentration of coarse aerosols depending on the length of the underground excavation at the height above the floor approx. $1.55 \mathrm{~m}$. It was observed that the results obtained during in situ measurements were comparable with the results obtained from the numerical simulations. The concentration of coarse aerosols at a height above the floor of $1.55 \mathrm{~m}$, depending on the length of the underground excavation for a given temperature, velocity, and relative humidity conditions of air, can be predicted by the equations:

- $\quad$ Based on the in-situ measurements:

$$
\text { aerosol }_{\text {coarse }(1.55 m)}=0.1726\left(L_{T}-L_{B}\right)^{2}-22.277\left(L_{T}-L_{B}\right)+720
$$

- $\quad$ Based on the numerical simulations:

$$
\text { aerosol }_{\text {coarse }(1.55 m)}=9 e^{-8}\left(L_{T}-L_{B}\right)^{2}-1 e^{-5}\left(L_{T}-L_{B}\right)+0.0003
$$



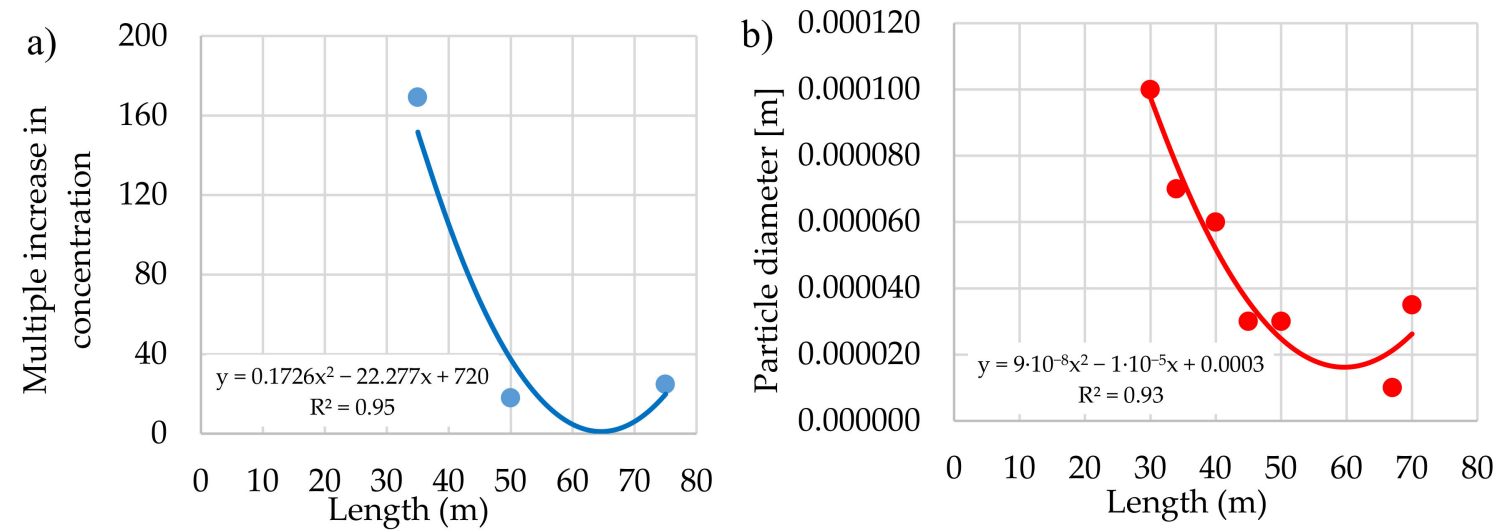

Figure 16. Comparisons of the concentration and the particle diameter of coarse aerosols depending on the length of the underground excavation at the height above the floor $1.55 \mathrm{~m}$ : (a) in situ measurements, (b) CFD calculations.

For ultrafine aerosols in the range $15 \div 100 \mathrm{~nm}$, the distribution of concentration changes is shown in Figure 17. The graph also takes into account the values of changes in the concentration of ultrafine aerosols, which constitute the natural environmental background of the underground excavation.

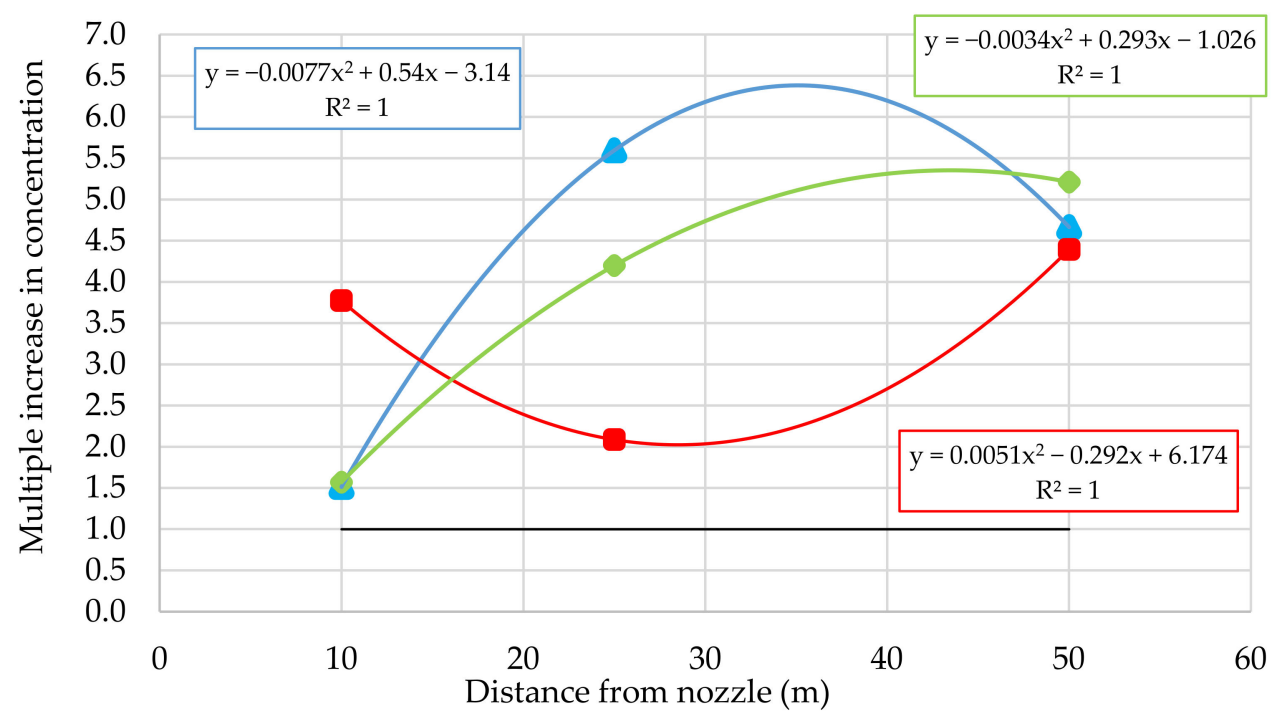
Left sidewall
Middle area
Right sidewall
Background

Figure 17. Distribution of the concentration of ultrafine aerosols as a function of the distance from the nozzle at a height of $1.55 \mathrm{~m}$ above the excavation floor.

Measurement of aerosols made at the height of $1.55 \mathrm{~m}$ above the floor of the excavation (Figure 17) show an increase in concentration on the left and right sidewall. However, in the axis of the excavation, the concentration of aerosols decreases with the distance from the nozzle. The concentration of ultrafine aerosols at a height above the floor of $1.55 \mathrm{~m}$, depending on the distance from the source of injection, can be predicted by equations:

- $\quad$ At the left sidewall:

$$
\text { aerosol }_{\text {ultra fine }(1.55 m)}=-0.0077 d^{2}+0.543 d-3.144
$$

- $\quad$ At the middle area:

$$
\text { aerosol }_{\text {ultra fine }(1.55 \mathrm{~m})}=0.0051 d^{2}-0.2915 d+6.1742
$$


- $\quad$ At the right sidewall:

$$
\text { aerosol }_{\text {ultra fine }(1.55 m)}=-0.0034 d^{2}+0.2932 d-1.0259
$$

Comparing the graph of the concentration changes of coarse aerosols obtained from the numerical calculation (Figure 13) with the in situ measurement results (Figure 15a) at a height of $1.55 \mathrm{~m}$ above the floor, it can be observed that the numerical model developed in the Ansys-Fluent software showed the range of coarse aerosols at a distance of $30 \mathrm{~m}$ from the nozzle ( $55 \mathrm{~m}$ from the inlet of the excavation), while the Ansys-CFX software at a distance of up to $60 \mathrm{~m}$, which coincided with the actual measurement results presented in Figure 15a.

For measurements of coarse aerosols at as height of $0.65 \mathrm{~m}$ above the excavation site floor, the actual measurement results (Figure 15b) showed an increase in concentration, similar to the numerical calculations presented in Figure 12a.

If the results of the changes in the concentration of ultrafine aerosols in the graph in Figure 17 are compared with the results of numerical calculations presented in Figure $12 \mathrm{c}, \mathrm{d}$, the trend in the increase in aerosol concentration measured at a height of $1.55 \mathrm{~m}$ on the floor of the excavation can be observed. On a section of $28 \mathrm{~m}$ ( $5 \mathrm{~m}$ from the nozzle) from the inlet to the model excavation, numerical simulations showed an increase in the size of coarse aerosol particles in the excavation, similarly to real measurements. Moreover, along the length of the excavation approximately $50 \mathrm{~m}$ ( $25 \mathrm{~m}$ from the nozzle), numerical simulations have shown the maximum aerosol particle size values. Additionally, in this length of the excavation section, numerical calculations showed the inlet of the aerosol particle size drop until complete evaporation, which was observed at a distance of $60 \mathrm{~m}$ (45 $\mathrm{m}$ from the nozzle) from the excavation inlet.

\section{Conclusions}

The paper presented the results of transporting aerosol particles in the air that ventilates a section of the underground excavation separated from the Experimental Mine Barbara ventilation network as well as the implementation of a numerical model using computational fluid dynamics (CFD) methods. Ansys-Fluent and Ansys-CFX software were selected to analyze the aerosol transport process in the area limited by the geometry of the underground excavation. Ansys-Fluent and Ansys-CFX software allowed to calculate the velocity profile of the air/vapor mixture and to predict changes in aerosol morphology. The obtained values of the parameters of the developed numerical models were compared to the measurement results.

The results presented and the numerical model of aerosol transfer in the air ventilating the excavation based on the application of CFD methods provide the following conclusions:

- The use of numerical CFD fluid mechanics methods made it possible to present quantitatively and qualitatively the process of aerosol transport in the space limited by the geometry of the underground excavation;

- The simulated distribution of aerosol morphology changes was comparable to the results of aerosol concentration changes observed at the actual laboratory scale;

- The velocity and position of aerosol particles along the excavation depended on the ventilating method and so the manner of the inlet locations to the excavation;

- The results of the obtained numerical solution showed that for the assumed parameters of ventilation air, aerosol particles up to a size below $50 \mu \mathrm{m}$ were completely evaporated, aerosol particles with sizes ranging from 50 to $110 \mu \mathrm{m}$ were transferred from 10 ( $35 \mathrm{~m}$ from the inlet of the excavation) to $60 \mathrm{~m}$ ( $85 \mathrm{~m}$ from the inlet of the excavation) with respect to the position of the nozzle, while aerosols above $110 \mu \mathrm{m}$ fell directly on the floor and the sidewall of the excavation up to $10 \mathrm{~m}(35 \mathrm{~m}$ from the inlet of the excavation) with respect to the position of the nozzle; 
- The increase in the concentration of aerosols on the right and left sidewalls of the excavation, shown during actual measurements and numerical simulations, was caused by the swirling of the air and water vapor mixture along the underground excavation;

- The demonstration of significant correlations between the tested variables obtained from the CFD analysis from the 3D model system and the results obtained through in situ tests confirm that the assumptions made were adequate for the numerical model;

- The demonstration of significant correlations between the tested variables obtained from the CFD analysis from the 3D model system and the results obtained through in situ tests confirm that the assumptions adopted for the numerical model were adequate;

- Determining the values of output variables from the numerical model allowed for a simple and easy interpretation of the phenomena occurring during aerosol transport in the ventilation air stream;

- The knowledge of the process of transporting aerosols in underground excavations and determining the decision parameters of the (controllable) numerical model, which influenced its course, gives the basis for understanding and controlling the whole process;

- In order to minimize COVID-19 spread in underground excavations, especially the most penetrating droplets in the range of $80-110 \mu \mathrm{m}$, as shown by the results of the numerical studies (Figure 14d,g), it should be used a local mechanical intensification of the ventilation of underground excavations and the use of air purification systems, the basic structural element of which are the non-woven fabrics filters, characterized by an extensive spatial structure;

- Comparing experimental results with CFD showed a relative error larger than $15 \%$; therefore, it is recommended to switch the model in the calculation to a better turbulence model. This is because the standard $k-\varepsilon$ model is not capable of capturing the streamline curvature (which is important in this case to show reasonable directions and re-circulations), poor near-wall values as shown in Table 5, over prediction of the turbulence parameters, and many other shortcomings that are typical for the standard $\mathrm{k}-\varepsilon$ model.

Author Contributions: Conceptualization, T.J. and Z.L.; methodology, T.J. and L.Ś.; software, T.J. and L.Ś.; validation, T.J. and L.Ś.; formal analysis, T.J., Z.L., L.Ś., A.W. and J.J.; investigation, T.J. and L.Ś.; resources, T.J.; data curation, T.J. and L.S.; writing—original draft preparation, T.J., L.S. and A.W.; writing—review and editing, T.J., Z.L., L.Ś., A.W. and J.J.; visualization, T.J. and L.Ś.; supervision, J.J.; project administration, Z.L.; funding acquisition, Z.L. All authors have read and agreed to the published version of the manuscript.

Funding: This research was funded by the Ministry of Science and Higher Education, grant number 11132020-110.

Institutional Review Board Statement: Not applicable.

Informed Consent Statement: Not applicable.

Data Availability Statement: Data available on request due to the fact of restrictions, e.g., privacy or ethical.

Acknowledgments: This work was conducted as part of statutory research at the Central Mining Institute (No. 11132020-110), financed by the Ministry of Science and Higher Education, Poland.

Conflicts of Interest: The authors declare no conflict of interest.

\section{Nomenclature}

$A, B, C \quad$ Empirical constants (-)

$d \quad$ Distance from the nozzle $(\mathrm{m})$

$L_{t} \quad$ Distance from the inlet of the excavation $(\mathrm{m})$

$L_{B} \quad$ Distance from the nozzle (m)

$p_{\text {vap }} \quad$ Partial vapor pressure $(\mathrm{Pa})$ 


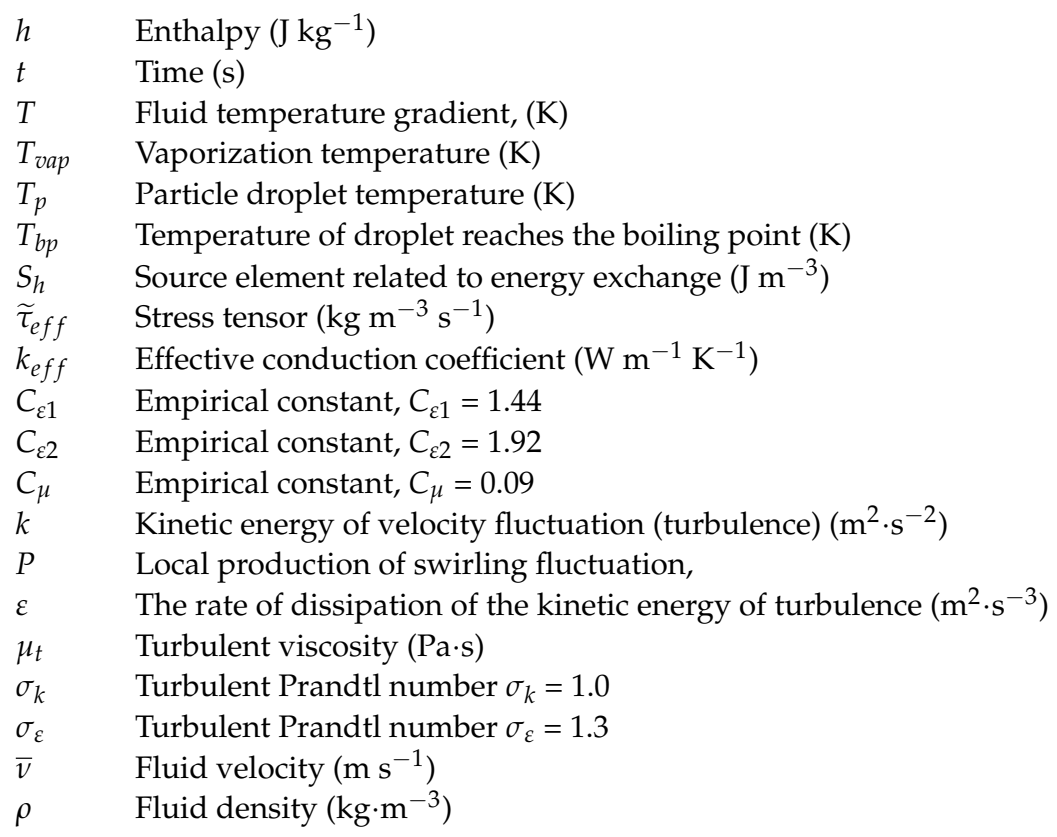

\section{References}

1. WHO. Summary of Probable SARS Cases with Onset of Illness from 1 November 2002 to 31 July 2003. Available online: https://www.who.int/csr/sars/country/table2004_04_21/en/ (accessed on 24 July 2015).

2. WHO. Middle East Respiratory Syndrome Coronavirus (MERS-CoV). Available online: https://www.who.int/emergencies/ mers-cov/en/ (accessed on 19 January 2019).

3. WHO. WHO Coronavirus Disease (COVID-19) Dashboard. Available online: https://covid19.who.int (accessed on 21 March 2020).

4. WHO. Situation by Region, Country, Territory \& Area. Available online: https://covid19.who.int/table (accessed on 21 March 2020).

5. Moskal, A.; Sosnowski, T.R. Aerosol Mechanics; Oficyna Wydawnicza Politechniki Warszawskiej: Warsaw, Poland, 2017.

6. Feng, Y.; Marchal, T.; Sperry, T.; Yi, H. Influence of wind and relative humidity on the social distancing effectiveness to prevent COVID-19 airborne transmission: A numerical study. J. Aerosol Sci. 2020, 147, 105585. [CrossRef] [PubMed]

7. Tang, J.W.; Lib, Y.; Eames, I.; Chan, K.S.; Ridgway, G.L. Factors involved in the aerosol transmission of infection and control of ventilation in healthcare premises-Review. J. Hosp. Infect. 2006, 64, 100-114. [CrossRef] [PubMed]

8. Bourouiba, L. Turbulent Gas Clouds and Respiratory Pathogen Emissions. JAMA 2020, 323, 1837-1838. [CrossRef] [PubMed]

9. Asadi, S.; Wexler, A.S.; Cappa, C.D.; Barreda, S.; Bouvier, N.M.; Ristenpart, W.D. Aerosol emission and super emission during human speech increase with voice loudness. Sci. Rep. 2019, 9, 2348. [CrossRef] [PubMed]

10. Mittal, R.; Ni, R.; Seo, J.-H. The flow physics of COVID-19. J. Fluid Mech. 2020, 894, F2. [CrossRef]

11. Dbouk, T.; Drikakis, D. On coughing and airborne droplet transmission to humans. Phys. Fluids 2020, 32, 053310. [CrossRef] [PubMed]

12. Anfinrud, P.; Stadnytskyi, V.; Bax, C.E.; Bax, A. Visualizing Speech-Generated Oral Fluid Droplets with Laser Light Scatterin. N. Engl. J. Med. 2020, 382, 2061-2063. [CrossRef] [PubMed]

13. Chao, C.Y.H.; Wan, M.P.; Morawska, L. Characterization of expiration air jets and droplet size distribution immediately at the mouth opening. J. Aerosol Sci. 2009, 40, 122-133. [CrossRef]

14. Lee, B.U. Minimum size of respiratory droplets containing SARS-CoV-2 and aerosol transmission possibility. Int. J. Environ. Res. Public Health 2020, 17, 6960. [CrossRef] [PubMed]

15. Zhang, H.; Li, D.; Xie, L.; Xiao, Y. Documentary Research of Human Respiratory Droplet Characteristics. Procedia Eng. 2015, 121, 1365-1374. [CrossRef] [PubMed]

16. Stadnytskyia, V.; Baxb, C.E.; Baxa, A.; Anfinruda, P. The airborne lifetime of small speech droplets and their potential importance in SARS-CoV-2 transmission. Med. Sci. 2020, 117, 11875-11877. [CrossRef] [PubMed]

17. Zhu, S.; Yang, J.-H. Study on transport characteristics of saliva droplets produced by coughing in a calm indoor environment. Build. Environ. 2006, 41, 1691-1702. [CrossRef]

18. Settles, G. Small droplet aerosols in poorly ventilated spaces and SARS-CoV-2 transmission. Lancet Respir. Med. 2020, 8, 658-659.

19. Redrow, J.; Mao, S.; Celik, I.; Posada, J.A.; Feng, Z. Modelling the evaporation and dispersion of airborne sputum droplets expelled. Build. Environ. 2011, 46, 2042-2051. [CrossRef]

20. Scanning Mobility Particle Sizer Spectrometer 3936. Available online: https://tsi.com/discontinued-products/scanning-mobilityparticle-sizer-spectrometer-3936/ (accessed on 21 March 2020). 
21. Aerodynamic Particle Sizer (APS) Spectrometer 3321. Available online: https:/ tsi.com/products/particle-sizers / particle-sizespectrometers/aerodynamic-particle-sizer-(aps)-spectrometer-3321/ (accessed on 21 March 2020).

22. ANSYS Fluent User's Guide (2013). Release 18.0; ANSYS, Inc.: Osaka, Japan, 2013.

23. ANSYS CFX-Solver Theory Guide. Release 18.0; ANSYS, Inc.: Osaka, Japan, 2020.

24. Polish Standard PN-93/G-15000/02. Steel Arch Supports ŁP for Mining Workings. Dimensions; Polish Committee for Standardization: Warsaw, Poland, 1993.

25. Chandranegara, A.; Wenten, I.G. CFD Turbulence Model of Tangential Cylindrical Cyclone for Droplets Removal from Gas Streams. In Proceedings of the International Seminar on Chemical Engineering Soehadi Reksowardojo, Kupang, Indonesia, 7-9 October 2019. 